UNITED STATES DEPARTMENT OF THE INTERIOR

GEOLOGICAL SURVEY

LATE DIAGENETIC INDICATORS OF BURIED OIL AND GAS

By

Terrence J. Donovan and Mary C. Dalziel

Open-File Report 77-817

1977

This report is preliminary and has not been edited or reviewed for conformity

with U.S. Geological Survey standards and nomenclature 
Table of Contents

Page

ABSTRACT- -

INTRODUCTION- - -

INTERACTIONS BETWEEN WATER AND HYDROCARBONS- -

IDENTIFICATION OF ALTERED CRUDE OILS

CUMULATIVE EFFECTS OF HYDROCARBON SEEPAGE THROUGH SURFACE AND NEAR

SURFACE ROCKS--

Isotopic Data-c- 11

Case I- $1-10-13$

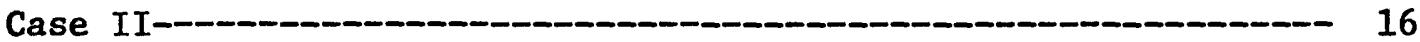

Case III-C-C-C-C- 17

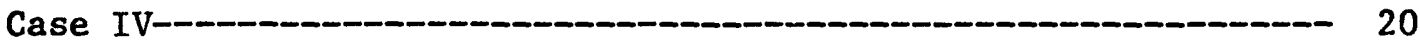

Chemical Data--- - -

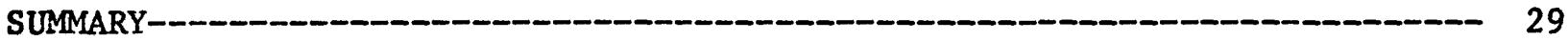

ISOTOPIC AND CHEMICAL ANALYSES- -

Isotopic Data- 36

Chemical Data--

REFERENCES CITED- - 


\title{
LATE DIAGENETIC INDICATORS OF BURIED OIL AND GAS
}

\author{
By Terrence J. Donovan ${ }^{1}$ and Mary C. Dalziel ${ }^{2}$ \\ Flagstaff, Arizona 86001, and Denver, Colorado 80225
}

\begin{abstract}
At least three hydrocarbon seepage mechanisms are interpreted to operate over oil and gas fields. These are: (1) effusion of hydrocarbons through inadequate caprocks and along faults and fractures, (2) low-molecular-weight hydrocarbons dissolved in water moving vertically through capping shales as a result of a hydrodynamic or chemical potential drive, and (3) diffusion of gases dissolved in water. Combinations of these mechanisms may also occur.

Seeping hydrocarbons are oxidized near the earth's surface, and the resulting carbon dioxide reacts with water producing bicarbonate ions, which combine with calcium and magnesium dissolved in ground waters to yield isotopically distinctive pore-filling carbonate cements and surface rocks. The passage of hydrocarbons and associated compounds such as hydrogen sulfide through surface rocks causes a reducing environment and consequent reduction, mobilization, and loss of iron from iron-bearing minerals commonly resulting in a discoloration. Other metals such as manganese are also mobilized and redistributed. These changes in the physical and chemical properties of surface rocks correlate with the subsurface distributiois of petroleum, and potentially can be detected from both airborne and spaceborne platforms.
\end{abstract}

\section{INTRODUCTION}

Explorationists have long utilized seepages and other surface indicators of petroleum as guides to the location of exploratory drill sites (Owen, 1975; Thompson, 1926; Barton, 1927; Coomber, 1938; Illing, 1938; DeGolyer, 1940; Link, 1952). The most obvious and easily found petroleum deposits were discovered largely by the use of surface seepages, and by detailed mapping of the surface expression of structural traps. More recently sophisticated techniques geared to detection of trace amounts of hydrocarbons in soils and soil gases and the metabolic byproducts of microbial degradation of hydrocarbons at the surface have been employed (Laubmeyer, 1933; Sokolov, cited in Boyle and Garrett, 1970; Horvitz, 1939; Pirson, 1940; Rosaire, 1940; Kartsev and others, 1959; Davis, 1967; Boyle and Garrett, 1970). The difficulty in finding geologically inconspicuous deposits also stimulated the development of a highly sophisticated geophysical technology. The success of this technology, coupled with the fact that the "easy oil" largely had been found, was responsible for a decline in interest in surface indicators of buried petroleum. Recently, however, the large and increasing costs of geophysical surveying have spurred renewed interest in detection of subsurface accumulations of petroleum by surface or near surface indicators (McCulloh, 1969; Donovan, 1974; Donovan, Noble, and others, 1975).

IU.S. Geological Survey, 2255 North Gemini Drive.

2U.S. Geological Survey, Box 25046, Denver Federal Center. This work was supported in part by NASA contract S-54039A. 
This paper describes several kinds of surface alteration phenomena over several midcontinent, Texas, California, and Rocky Mountain oil fields and one undrilled prospect, and proposes, schematically, the geochemical pathways whereby they may be developed.

\section{INTERACTIONS BETWEEN WATER AND HYDROCARBONS}

The subtle relationships between formation-water salinity and dispersal, transport, and remobilization of entrapped hydrocarbons are not always recognized. The origin of saline-formation waters (brines) is a major geochemical and hydrologic problem (Clayton and others, 1966), and important to many of the problems in the geology of petroleum. The conclusion that formation waters are "predominantly of local meteoric origin" (Clayton and others, 1966, p. 3869) is of special importance to the general problem of hydrocarbon-formation water interaction.

Hitchon (1969a, b; 1974), combined complex mathematical models of basinwide flow of fluids of Toth $(1962 ; 1963)$, Freeze $(1966 ; 1969)$, and Freeze and Witherspoon (1966; 1967; 1968), to substantiate that the critical variables affecting fluid potential distribution in a basin are topography, lithology, and permeability. Thus, "the dominant fluid potential in any part of the basin corresponds closely to the fluid potential at the topographic surface in that part of the basin. Major recharge areas correspond to major upland areas, and major lowland regions are major discharge regions" (Hitchon, 1974, p. 539). Topography provides and maintains the initial differences of fluid potential by capturing precipitation at different elevations.

However, it is because most sedimentary rocks are anisotropically permeable that ground-water flow lines tend to parallel bedding; such anisotropy is usually insignificant in unconsolidated sediments. These facts enable sedimentary basins to be divided into two vertical zones (Toth, 1972): the unconfined flow zone has its flow distribution controlled by the configuration of the overlying water table and the confined zone has its flow system bounded by rock layers of low permeability; its flow distribution is not significantly influenced by the potential of the water table. Total dissolved solids (TDS) in the waters increase in the direction of flow and at the join of two flow systems; at points where three or more systems diverge, stagnant water forms which may be signalled by an increased total dissolved solids content. In areas of upward flow, accumulation of mineral salts may be expected in soils (Toth, 1972).

The capacity of clays and shales to act as salt-concentrating membranes is well established (DeSitter, 1947; Berry, 1959; Bredehoeft and others, 1963). Complementary studies of the effects of shale micropore systems on the isotopic fractionation of water provide additional evidence for regional recharge of subsurface waters by meteoric input (Graf and others, 1965; Graf and others, 1966; Hitchon and Friedman, 1969; Coplen and Hanshaw, 1973). Graf and others (1965) noted the difference in Deuterium and oxygen isotopic composition between pairs of samples taken from different depths but geographically similar positions, as an indicator of the direction of cross-formational flow in that area. Their data clearly indicate large meteoric-water input. The idea that oils can be altered by contact with low-salinity (meteoric) waters has been discussed for some time (Estabrook, 1925; Uspenskii and others, 1947; Hunt, 1953; Weeks, 1958; Krejci-Graf, 1963). Furthermore, it has recently been documented that 
low-salinity waters play an important role in the in situ biodegradation of crude oil (Winters and.Williams, 1969; Balley, Jobson, and Rogers, 1973). The selective removal from petroleum reservoirs of the low-molecular-weight components implies intricate subsurface relationships between major segments of the hydrologic and carbon cycles.

Figure 1 demonstrates the relationship between aqueous solubility and the molecular weight of homologous series compounds characteristic of crude oils at $25^{\circ} \mathrm{C}$ and 1 atmosphere pressure. The data clearly indicate that the low-molecularweight members of any homologous series present in crude are more soluble in water. For any given molecular weight, aromatic compounds are more soluble in water than normal paraffins (because of the polar character of the aromatic ring) and cycloparaffins with low- to moderate-molecular weights have intermediate aqueous solubilities. Further, the aqueous solubilities of branched-chain paraffin hydrocarbons are somewhat greater than normal paraffin hydrocarbons. McAuliffe (1963, p. 1093) stated that, with the exception of methanes, "it appears that to a first approximation the weight of a normal or branched-chain paraffin hydrocarbon which dissolves in water is proportional to the vapour pressure of the hydrocarbon." These kinds of data are broadly useful in hypothesizing how selected hydrocarbons might overcome physical barriers (such as low permeability and(or) high capillary pressure) to escape from petroleum reservoirs.

Complications arise when one considers interactions between hydrocarbons and impure water under a temperature and pressure regime such as is found in subsurface environments. Published data indicate that hydrocarbon solubility in water varies inversely with salt concentration, and is also dependent upon the kind of hydrocarbon and salt (Euchen and Hertzberg, 1950; McDevitt and Long, 1952; Paul, 1952; McAuliffe, 1963). The study of Price (1976) indicates that the increase of aqueous-solubility with temperature at systems' pressure is uniform but slight in the range $25^{\circ}$ to $100^{\circ} \mathrm{C}$, above which there is a pronounced increase. According to Price, salinities in excess of $150,000 \mathrm{ppm} \mathrm{NaC} 1$ concentation effect drastic exsolution of hydrocarbons, and at $350,000 \mathrm{ppm}$ there is about a 95 percent reduction in solubility. However, a semi-log plot of some of Price's data (fig. 2) indicates that a change from gradual to drastic exsolution begins at about $25,000 \mathrm{ppm}$. This is probably the result of abrupt transition between two different solution mechanisms. Therefore, drastic dissolution of hydrocarbon might be expected even with moderate dilution of formation waters.

The effects of increased temperature and pressure are counteractive to aqueous salt concentration; however, at conditions common to moderate-toshallow depths, pressure and temperature effects appear relatively unimportant (Price, 1976, figs. 2-9). Within the moderate-to-shallow depth range greatly variable formation water salinities are observed, however, they are commonly low (DeSitter, 1947; Bredehoeft and others, 1963; Dickey, 1966; Zaitsev and Baskov, 1969). Significant fresh-water dilution of brine systems can markedly affect the aqueous solubility of any hydrocarbons with which they are in contact, as well as introduce other complicating factors such as microbes, dissolved molecular oxygen, and sulfate.

Considered broadly, the introduction to a petroleum reservoir of relatively fresh water, possibly bearing dissolved oxygen or sulfate and hydrocarbon- 


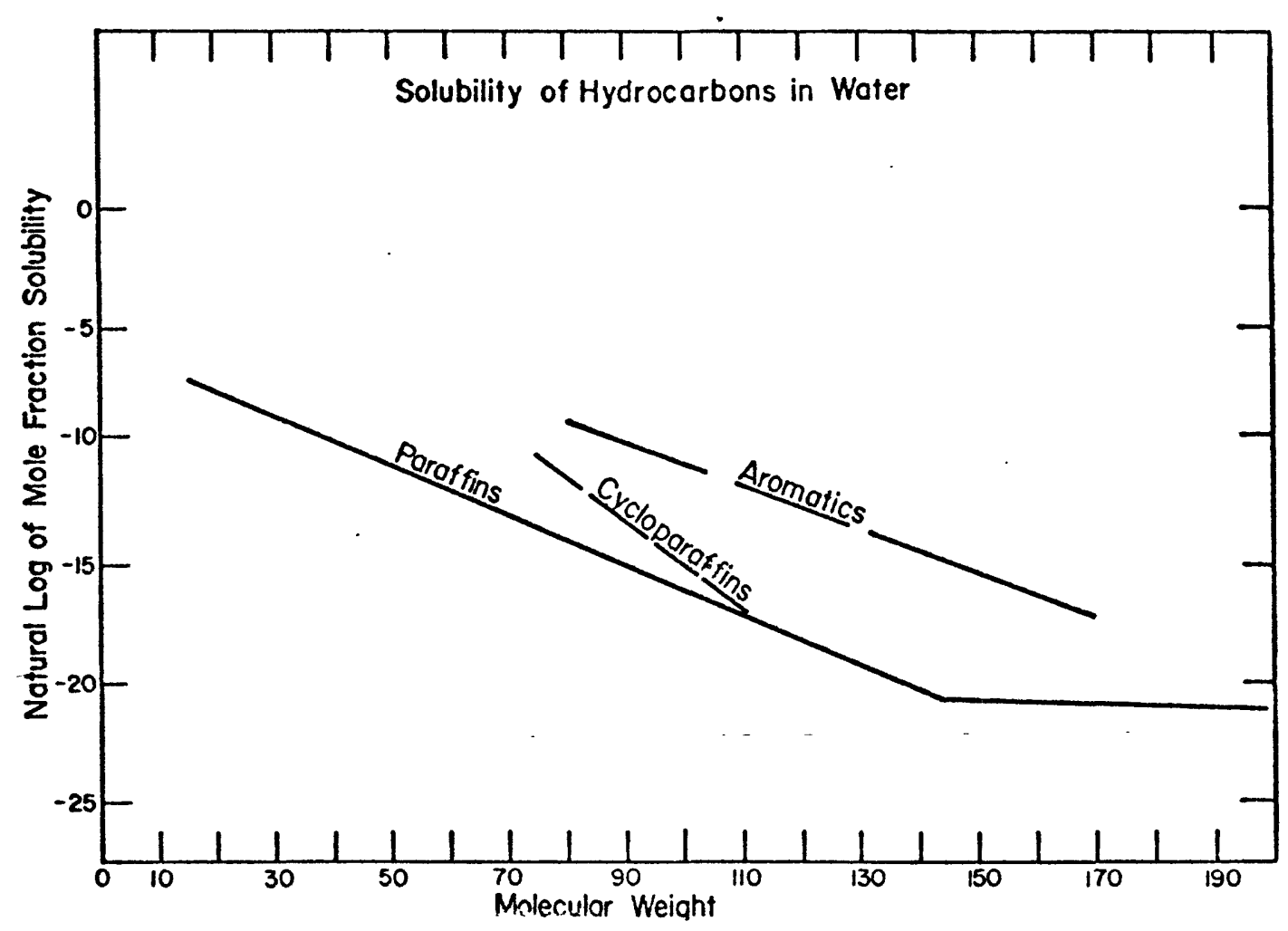

Figure 1.--Relation between molecular weight and aqueous solubility of homologous series compounds at $25^{\circ} \mathrm{C}$ and 1 atm pressure. Data from Bohon and Claussen (1951); McAuliffe (1963); and Baker (1969). The tabulated values of Price (1976, table 2) should also be consulted. 


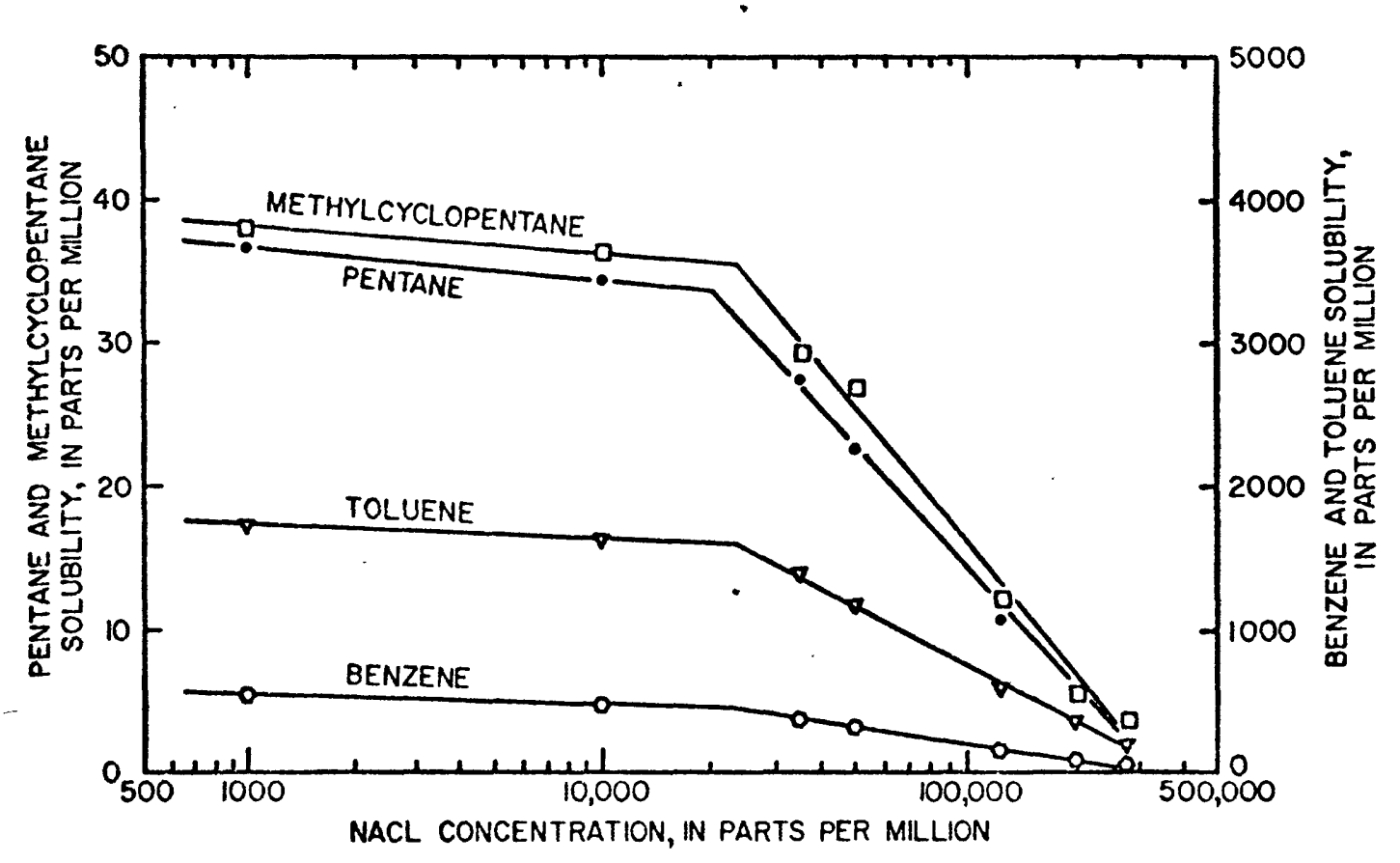

FIgure 2.--Relation between aqueous solubility of various hydrocarbons and salt concentration. Data from Price (1976). 
oxidizing microbes can result in the following: (1) in situ biodegradation of hydrocarbons, expecially the paraffins in approximate proportion to their chain length; and (2) dissolution and removal (water-washing) of the more watersoluble components (Winters and Williams, 1969; Bailey, Jobson and Rogers, 1973; Bailey, Krouse, and others, 1973; Donovan, 1974). These mechanisms plus the escape by direct communication with the surface (Hunt, 1953, p. 1870) leave behind a residual oil different in composition than the original material. Other factors affecting alteration, such as gas-deasphalting (Evans and others, 1971) or the addition of microbial metabolites (Winters and Williams, 1969), should also be considered.

\section{IDENTIFICATION OF ALTERED CRUDE OILS}

It is of interest to determine if microseepage from petroleum accumulations is common enough to make exploration techniques, based upon detection of this seepage, useful. The problem can be addressed by assuming that crude oils will be detectably altered if selective loss of the low-molecular-weight liquid components ("light-ends") has occurred. Leaky systems are expected to contain a residual petroleum substantially different than the "starting" substance. The following discussion describes processes which bring about this alteration.

Petroleum displays a wide variety of compositions and physical characteristics which are dependent upon the source materials and environment at the place of origin, the environment at the place of accumulation, and any subsequent chemical or biochemical changes (Andreev and others, 1968). The actual processes of generation, migration, and alteration are poorly understood, and empirical evidence for them is difficult to obtain. The general improvement in the quality of crude oil through a decrease in density with increasing depth and temperature is well known (Barton, 1934; Brooks, 1949; McNab and others, 1952) as is the general correlation in most basins between increasing specific gravity of petroleum and decreasing water salinity (Weeks, 1958). These variations have most commonly been interpreted as the result of thermal maturation of the crude oil, although Haeberle (1951) has related variations in crude properties in the Gulf Coast region to changes in depositional facies. The inverse relation between petroleum specific gravity and depth or temperature is highly variable and is qualitatively true only in restricted areas or some geologic provinces (for instance, in areas such as the Texas Gulf Coast). Reversals of the trend are common (Levorsen and Berry, 1967, p. 162; Schmidt, 1973; Kharaka and others, 1977).

Study of data tabulated in U.S. Bureau of Mines Routine Crude-Petroleum Analyses (Hempel-method analyses) suggests a more than casual relationship between the volume percent of Total Gasoline and Naphtha (TG+N) fraction (hydrocarbons distilling between $50^{\circ}$ and $200^{\circ} \mathrm{C}$ at $760 \mathrm{~mm} \mathrm{Hg}$ ) and that fraction's specific gravity. Low volumes are characteristically associated with high specific gravities and the opposite is true. Because specific gravity is a measure of hydrocarbon composition, it is apparent that as the volume percent of $\mathrm{TG}+\mathrm{N}$ varies so does its composition. A normalization technique was devised to preclude comparisons of $\mathrm{TG}+\mathrm{N}$ volumes which are compositionally different:

$$
\mathrm{TG}+\mathrm{N}^{*}=\mathrm{TG}+\mathrm{N}\left(\frac{\mathrm{Sp} \cdot \mathrm{g}}{\mathrm{Sp \cdot g}}\right),
$$


where $\mathrm{TG}+\mathrm{N}^{*}$ is the normalized volume percent of the total gasoline and naphtha reported in the U.S. Bureau of Mines Routine Analysis, Sp. $g$ is the specific gravity of that fraction, and $\overline{\mathrm{Sp} \cdot \mathrm{g}}$ is the mean specific gravity $(.746)$ calculated from all the data used (154 analyses).

Cursory inspection of the normalized data suggests that $\mathrm{TG}+\mathrm{N}^{*}$ varies with salinity, for in general there is a small $\mathrm{TG}+\mathrm{N}^{*}$ associated with low-salinity waters as expected, but the relationship is neither simple nor linear. A plot of $\log \mathrm{TG}+\mathrm{N}^{*}$ against the $\log$ of the square of salinity (in percent) suggests strongly a relation exists but a marked heterogeneity is exhibited (fig. 3 ).

If alterations as outlined above have occurred in a reservoir, it is reasonable that no consistent relation should exist between $\mathrm{TG}+\mathrm{N}^{*}$ and salinity, except that TG+N* will be small for the corresponding total salinity. The test of this presumption is data plotted (fig. 3) for crudes known from chemical (and geological) analysis to be both "normal" and peculiar (and presumably altered) with respect to their compositions. The location of samples used for control are tabulated in table 1. Thus, although the data for the oils plotted in figure 3 are from Hempel analyses, the assessment of their altered or unaltered nature is from other sources. Salinities of formation waters are taken from U.S. Bureau of Mines published and unpublished sources. Only salinities for a formation water that is associated with a crude oil were used.

Figure 4 is a plot of unaltered crudes from figure 3 as a function of salinity demonstrating a good correlation. The gentle slope of the regression curve testifies to the sparing solubility of hydrocarbons in salt water.

It is emphasized that the dashed line drawn on figure 3 is not a statistically fitted curve, rather it is a subjective separation of data points representing two distinct classes of oils: those essentially in equilibrium with their associated waters (above the line), and those in disequilibrium (below the line). The latter are the result of some unusual post-accumulation history. An inequality can be calculated from these empirical data which is useful for estimating unaltered crude oils:

$$
\mathrm{TG}+\mathrm{N}^{*}>[\mathrm{TDS}]^{0.082}+25.7 \text {, }
$$

where [TDS] represents the percentage of total. dissolved solids in the associated formation waters. We conclude from figure 3 that altered crude oils are probably as common as unaltered ones, and a significant proportion may have been altered through the selective loss (in contrast to biodegradation) of light-ends.

\section{CUMULATIVE EFFECTS OF HYDROCARBON SEEPAGE THROUGH SURFACE} AND NEAR SURFACE ROCKS

Our data and analysis indicate that at least three seepage mechanisms operate. These are: (1) effusion of small to large amounts of gaseous and liquid hydrocarbons through relatively thin overburden along faults and fractures and through poorly compacted and permeable caprocks, (2) low-molecular-weight hydrocarbons dissolved in water moving vertically through capping shales behaving as semi-permeable membranes with either hydrodynamic pressure or differences in 


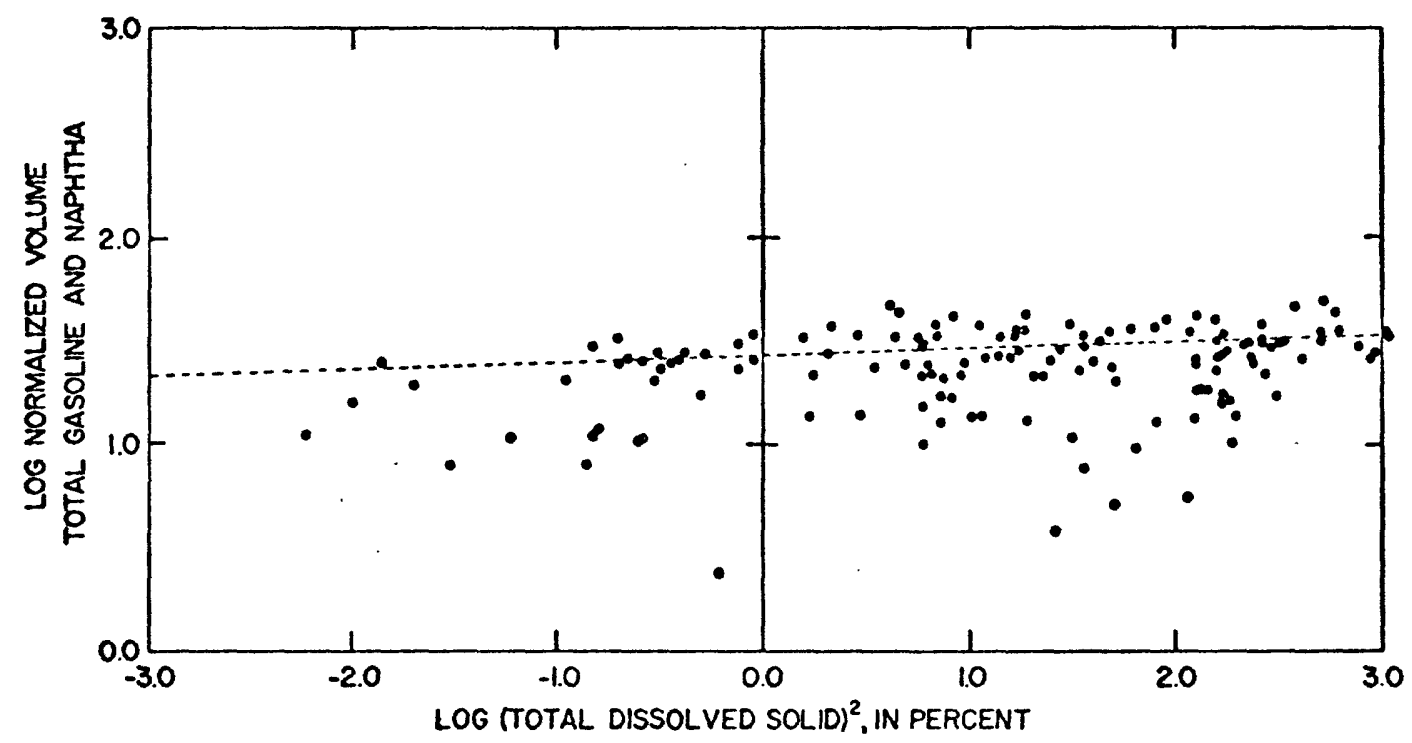

Figure 3.--Relation between normalized volume of Total Gasoline and Naphtha $(T G+N)$ in crude oil and total dissolved solids of associated formation waters. Dashed line separates unaltered crudes above from altered crudes below. 


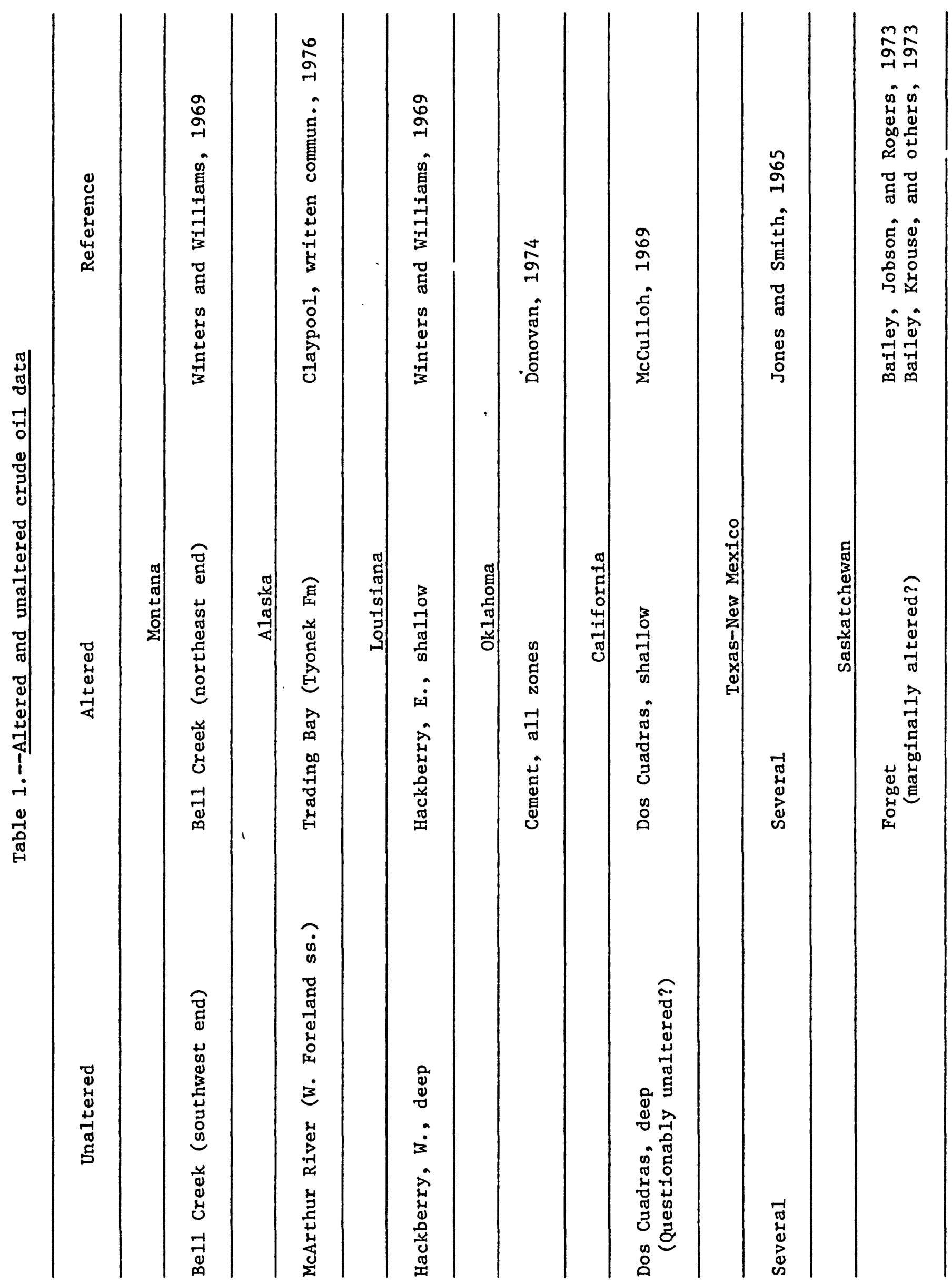




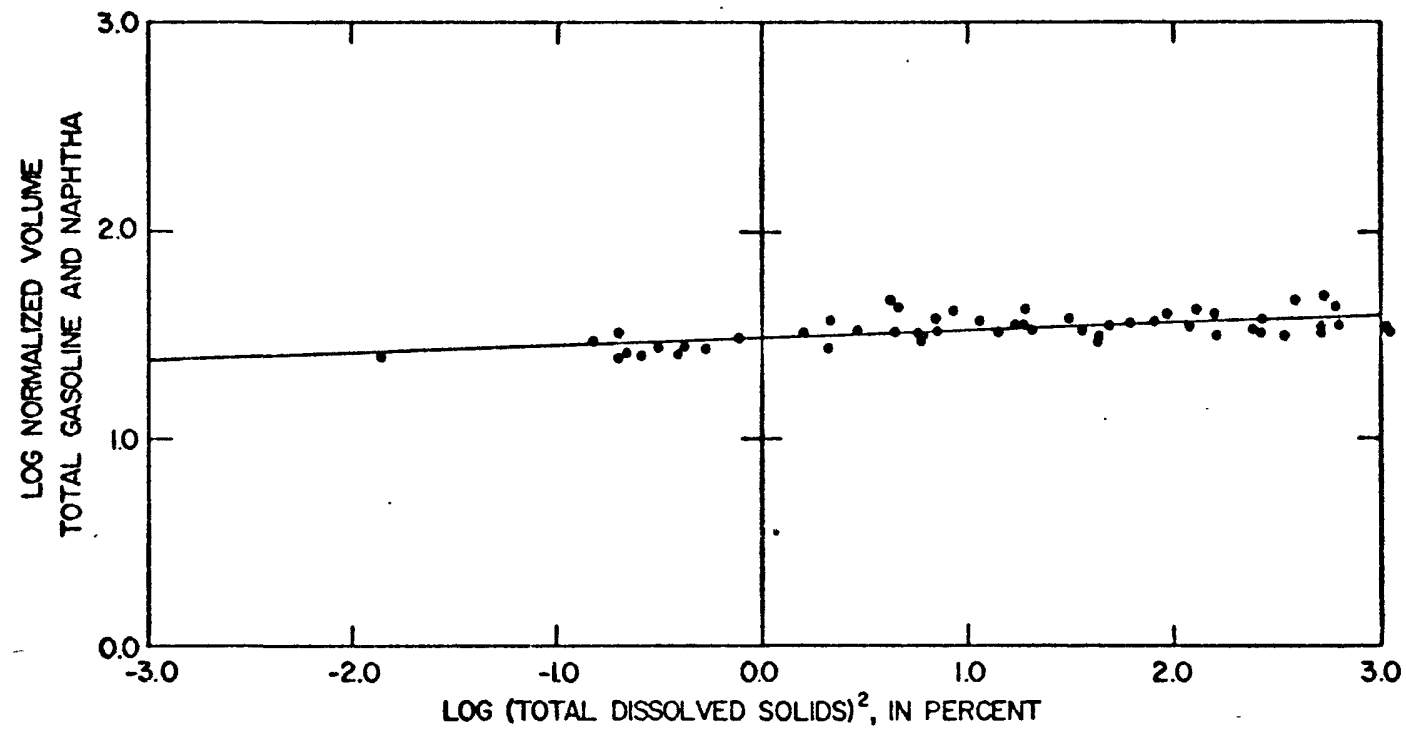

Figure 4.--Relation between normalized value of Total Gasoline and Naphtha $(T G+N)$ in unaltered crudes (as identified in fig. 3) and total dissolved solids of associated formation waters. 
chemical potential on opposite sides of the membranes providing the driving force, and (3) diffusion of dissolved gases through caprocks. Combinations of these processes also operate. Identification of the responsible mechanism is based on distinctive isotopic and chemical parameters of the surface rocks and in some cases, fluids, from underlying reservoirs. The cumulative effects are these: $C^{13}$ depleted carbonates are either $0^{18}$ enriched or impoverished depending upon which of the three main mechanisms has been dominant at an oil field. Furthermore, they are enriched with manganese and sometimes iron. Uncemented rock is commonly bleached or tinted because of reduction of iron in ironbearing minerals and its subsequent dissolution and loss. How these effects may come about is discussed below. Data were obtained from the following oil fields: Bisti, New Mexico; Cement, Davenport, Doyle, Fox-Graham, and Velma, Oklahoma; Garza and Jameson Reef, Texas; and Kettleman Hills, California. In addition, a suspected petroleum-related geochemical anomaly at Gunbarrel Hill, Colorado, was investigated (Donovan, Noble, and others, 1975; Roberts and others, 1976).

\section{Isotopic Data}

The unusual carbon isotopic compositions of replacement carbonate minerals and authigenic cements in sedimentary rocks resulting from the oxidation of hydrocarbons is well documented (Thode and others, 1953; Feely and Kulp, 1957; Hathaway and Degens, 1968; Davis and Bray, 1969; Mamchur, 1969; Davis and Kirkland, 1970; Kirkland and Evans, 1976). However, few investigations have been published describing the complex interrelationship between anomalous carbon and oxygen isotopic variations in carbonate minerals over oil fields (Cheney, 1964; Donovan, 1974; Donovan and others, 1974). If the precipitation of carbonate cements with unusual isotopic compositions in clastic rocks overlying oil and gas deposits results from the oxidation of hydrocarbons and other processes utilizing hydrocarbons, then their presence could in itself provide a means of locating buried hydrocarbons.

The isotopic compositions of carbonate cements from rocks cropping out over the oil fields investigated display extremely wide ranges (table 2). These data suggest that in some instances high $\delta 0^{18}$ values correlate with low $\delta C^{13}$ values, and in other instances the opposite is true, with low $\delta 0^{18}$ values corresponding to low $\delta \mathrm{C}^{13}$ values. Both isotopic distributions vary in a systematic and areally mappable way (for example, Donovan, 1974, figs. 6 and 7; Donovan and others, 1974, figs. 2 and 3; Donovan, Nob1e, and others, 1974, plates 1 and 2). We interpret that the $\mathrm{C}^{13 / \mathrm{C}^{12}}$ values reflect the source of carbon, (petroleum or natural gas), and the efficiency of hydrocarbon transport into the near surface ground-water system and subsequent oxidation. In contrast, the wide-ranging $0^{18} / 0^{16}$ values are interpreted to reflect fractionation processes operating on ground and formation waters, but modified somewhat by mixing with fresh water. Fractionated water subsequently reequilibrates with authigenic cements. Two primary fractionation mechanisms appear to be natural gas-induced evaporation of ground water and micropore filtration of vertically moving formation water. Both mechanisms should also influence the TDS content of ground waters. Over some large oil fields such as Cement and Velma, Oklahoma, different processes may have operated at different localities at the same field. We find it useful, therefore to compare mean $0^{18} / 0^{16}$ values with the $\mathrm{C}^{13} / \mathrm{C}^{12}$ minimum for a particular field. This "means vs. extremes" approach results in comparison of data reflecting the processes which has predominated 


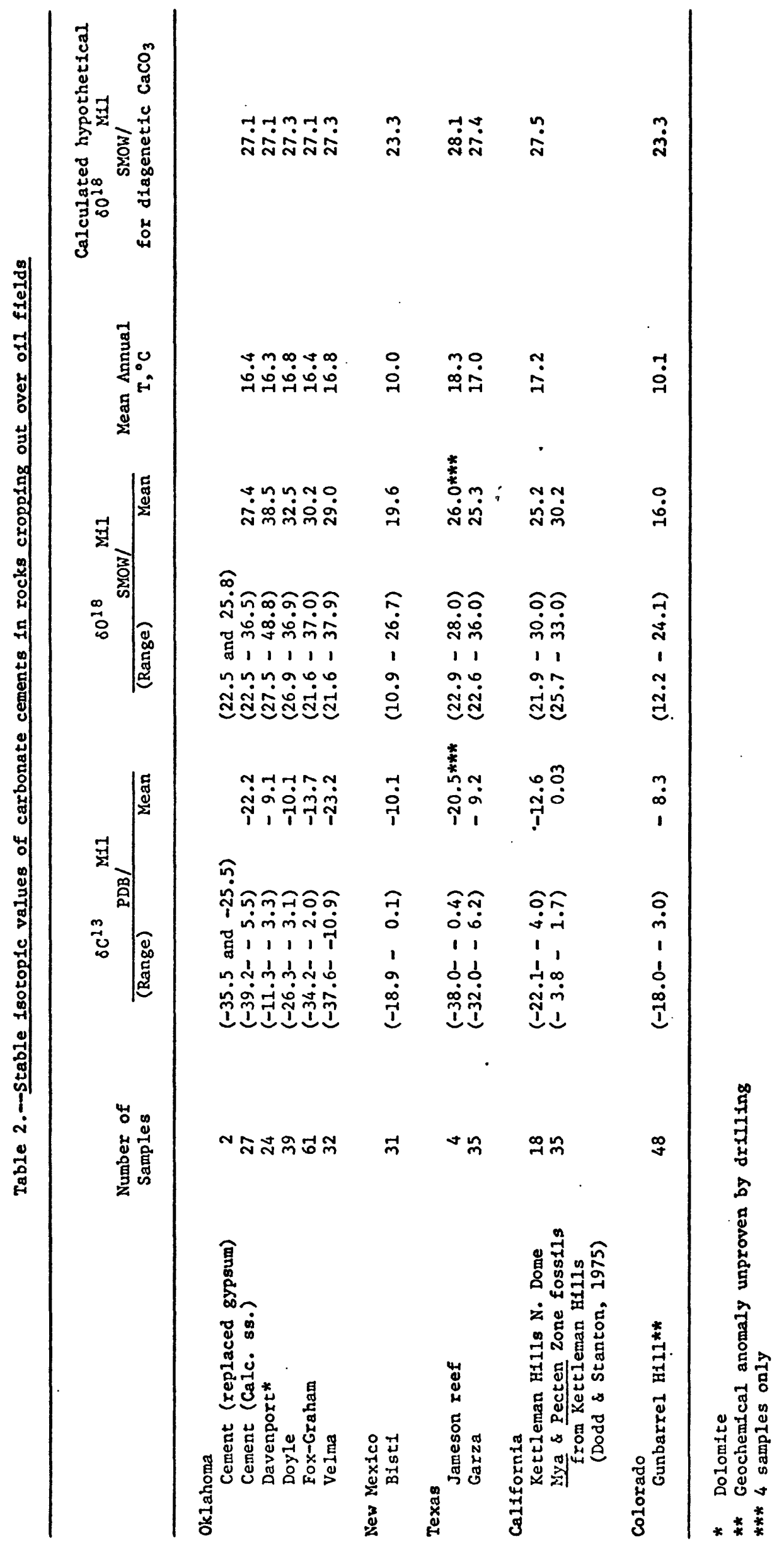


over an entire field. Figure 5 is a plot of $\delta \mathrm{C}^{13}$ ranges plotted at the mean $\delta 0^{18}$ position for nine known (and one unproven) oil fields. The range of values for typical marine, freshwater, and diagenetic carbonates are shown for comparison. A suggested envelope for our data is also sketched in.

At least one additional refinement of these data is possible. Because many of the areas of interest are considerably separated from one another geographically, the influence of present-day temperature on the $0^{18} / 0^{16}$ composition of the carbonates was considered. The theoretical $0^{18} / 0^{16}$ composition for calcite for each area was computed using the mean annual temperature for each region and the relationship between temperature and meteoric water (Dansgaard, 1964) and the $0^{18} / 0^{16}$ equilibrium constant for the water-calcite system at a given temperature (Clayton, 1961). Some mean values are close to theoretical, but many are not, suggesting fractionation processes have occurred which override the influence of temperature. To evaluate the latter, the absolute difference between mean and theoretical $0^{18} / 0^{16}\left(\Delta 0^{18}\right)$ was plotted against the most negative $\mathrm{C}^{13} / \mathrm{C}^{12}$ value for each area (fig. 6). Absolute differences were used in order to have sufficient data to calculate a curve, but the suggestion of parity is obvious from figure 5. It is important to note that as a mean $0^{18} / 0^{16}$ value deviates from "normal," $\delta \mathrm{C}^{13}$ decreases, and the relationship holds irrespective of the sign of $\Delta 0^{18}$. One explanation of these relationships is that they reflect the efficacy of trapping mechanisms in restraining selected hydrocarbons from escaping. It is not anticipated that additional data points would necessarily fall on the curves of figure 6. Rather we suggest that figures 5 and 6 define an approximate envelope within which most additzonal points will fall.

Case I: Origin of $0^{18}$-enriched carbonates.--The Davenport field of central Oklahoma provides a good model for this case. $\delta \mathrm{C}^{13}$ values in carbonate cements from outcrops over the field range from about $-5 / \mathrm{mil}$ to $-12 / \mathrm{mil}$. $\delta 0^{18}$ values likewise vary, but have an especially large range of $29 / \mathrm{mil}$ to $49 / \mathrm{mil}$. The lightest carbon and heaviest oxygen values are directly over the maximum oil column thickness (Donovan and others, 1974, figs. 2 and 3).

The Davenport field is in Lincoln County, Oklahoma. The discovery well was drilled in 1924 and found oil at 1,000 m. Rapid development followed and reached a peak during 1926. The surface rocks are Pennsylvanian shale, sandstone, and thin interbedded limestones. The first productive horizon is a thin Pennsylvanian sandstone at about $730 \mathrm{~m}$. The main producing horizon is a sandstone at $1,000 \mathrm{~m}$. This micaceous, lenticular sandstone has varying thicknesses $(10-33 \mathrm{~m})$ and grades into a sandy shale or pinches out entirely along the edge of the field. Less than $20 \mathrm{~km}^{2}$ are productive.

A small surface anticline exists at Davenport, but in the subsurface the producing area of the field extends beyond the limits of the structure and is controlled by the areal extent of the main producing sand. The oil produced at Davenport differs from that found in similar sands in other nearby localities because it is a paraffinic rather than mixed-base oil. The API gravity is $51^{\circ}$ (Brandenthaler and others, 1926; Radler, 1930; White, 1941; Donovan and others, 1974). Davenport was located by surface mapping.

Salinities of formation waters at Davenport approach 200,000 ppm. This precludes dissolution and removal in solution of large quantities of liquid 


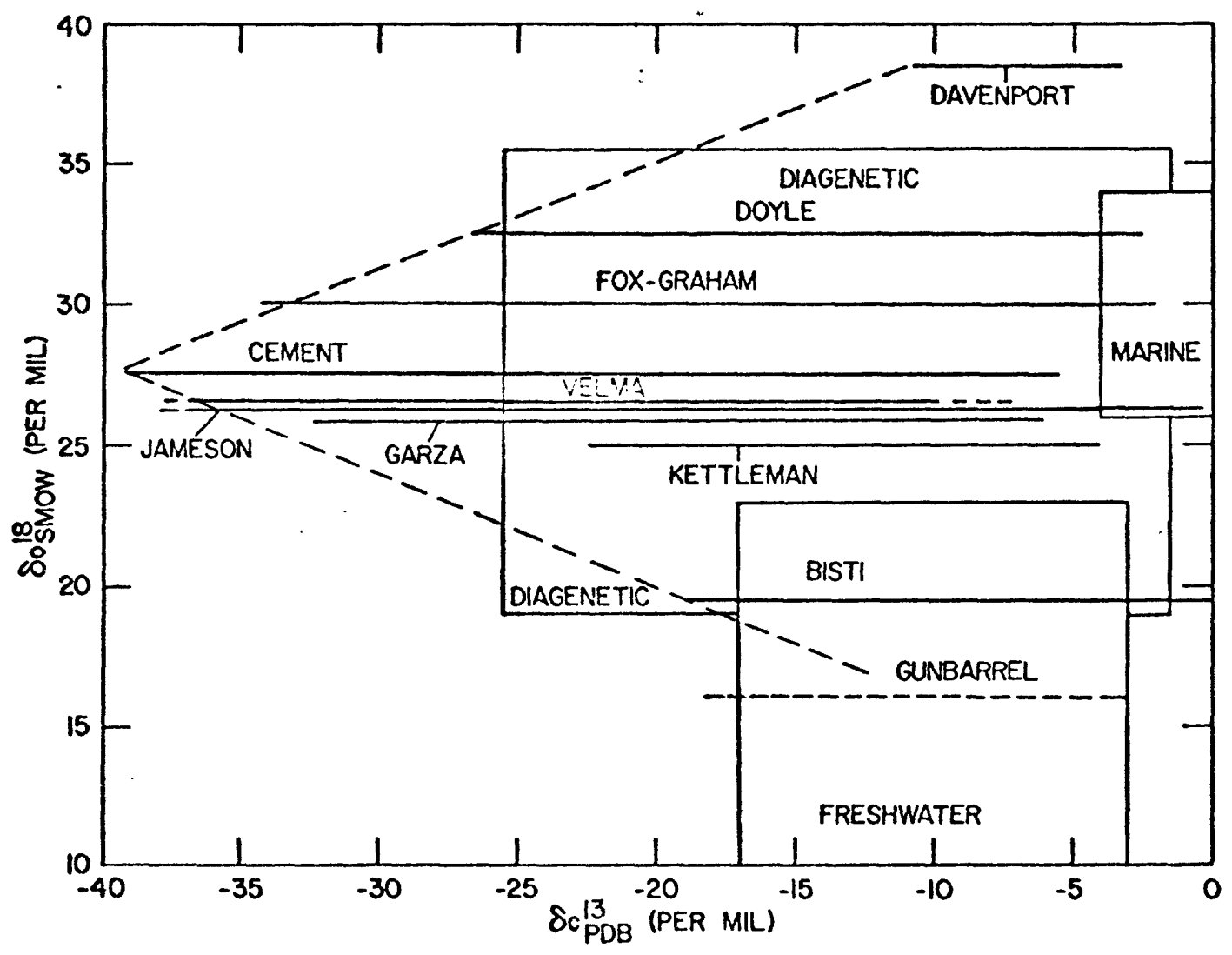

Figure 5.--Ranges of $\delta \mathrm{C}^{13}$ from carbonate cements in outcropping sandstones from 9 known and one suspected oil accumulations plotted at the mean $\delta 0^{18}$ position. Compositional limits of typical carbonates shown for comparison (Murata and others, 1969). A suggested envelope is also drawn (dashed line). 


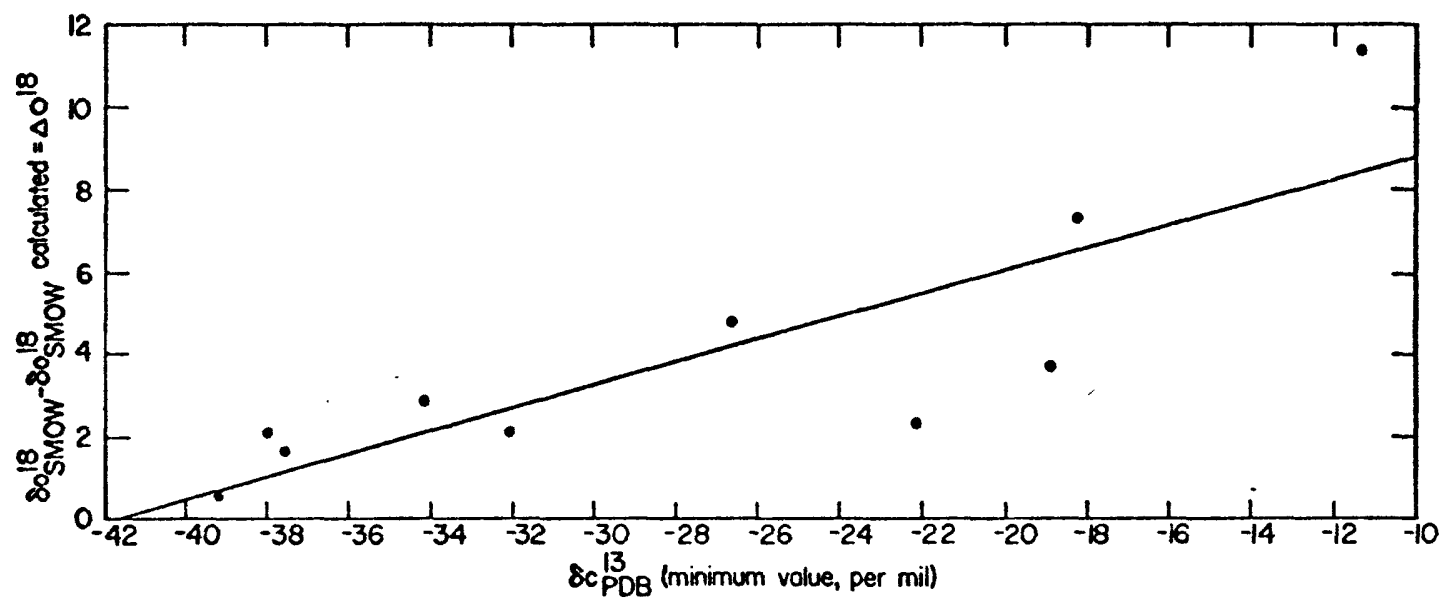

Figure 6.--Relation between the absolute difference between mean and theoretical $\delta 0^{18}\left(\Delta 0^{18}\right)$ and the most negative $\delta \mathrm{C}^{13}$ value found in carbonate cements of sandstones cropping out over ofl fields. 
hydrocarbons as an effective escape means. However, the petroleum there has an API gravity of $51^{\circ}$ and is considered a condensate (Brandenthaler and others, 1926). Escape of gas by diffusion thus appears logical. Diffusion of gaseous components usually takes place through the water phase. In this mode, the driving force is provided by concentration differences of gas in the liquid rather than involving the transfer of large amounts of dissolved constituents in a moving aqueous solvent. The experiments of Pandey and others (1974) show that although a gas in the liquid-water phase has a diffusion coefficient less than in the dry gas phase, the coefficient behaves similarly to that for bulk diffusion, and does not vary with pore size. Additionally, although the effects of pressure on the dry gas diffusion coefficients are different for high and low permeability rocks, "there are no pressure effects on diffusion coefficients through water-saturated rocks when the calculations are made on the basis of water phase concentrations" (Pandey and others, 1974, p. 301). Because the kinetic theory of gases does not hold for the diffusion of gases through the liquid-water phase, their evidence that the liquid bulk diffusivity does not vary with pore-radius is of major significance in explaining leaky fine-grained caprocks.

Gas-induced evaporation of ground water, initially proposed by Mills and Wells (1919) and confirmed as thermodynamically feasible by Nisle (1941), is the suggested fractionation mechanism for the large range of $\delta 0^{18}$ values found in carbonate cements at Davenport. Natural gas diffusing from the underlying deposit expands as it rises and comes out of solution. As it passes through ground water, it selectively evaporates $\mathrm{H}_{2} \mathrm{O}^{16}$ relative to $\mathrm{H}_{2} \mathrm{O}^{18}$ owing to differences in vafor pressure of the two waters (Rayleigh distillation). The $0^{18}$-enriched waters subsequently equilibrate with carbonates precipitating from mineralized pore waters. Data for evaporating waters in the Sahara indicate that Rayleigh distillation can fractionate surface water sufficiently to invest carbonates with similar $0^{18} / 0^{16}$ values (Fontes and Gonfiantini, 1967).

Case II: Origin of $0^{18}$-depleted carbonates.--The Bisti oil field in New Mexico provides an example of $0^{18}$-depleted carbonate cements overlying an oil field. Bisti is in southern San Juan County, New Mexico, on the southwest flank of the San Juan basin. The discovery well was drilled on a stratigraphic target in October 1955. Several other nearby pools were later discovered and linked together into the Bisti oil field.

Gas and oil occur in Upper Cretaceous off-shore marine bar sandstones. The bars grade into a silty shale, a forebar facies grading in a basinward direction (northeast) and a sandy shale or backbar facies in a southwest direction; the sandstones provide a series of narrow permeability lenses. There also is evidence of a positive hydrodynamic gradient caused by a northeastward (downdip) flow of water coupled with a decrease in updip permeability.

Significant gas is co-produced with oil and a limited free-gas cap exists at the updip edge. The oil has an average API gravity of $39^{\circ}$. Solution gas is the drive mechanism. The field contains 232 wells and the estimated ultimate recovery is 56 million barrels of oil (Devlin and Tomkins, 1957; McNeal, 1961; Sabins, 1963; Tomkins, 1957). 
The systematic areal variation of $0^{18 / 0^{16}}$ values which are on the average less than standard or theoretically determined values for carbonate-cemented rocks over oil fields implies potent and effective fractionation processes have been at work. Fractionation in the direction of $0^{18}$ depletion, however, is not difficult to explain. Given the constraints of the general geologic framework into which most oil fields fall and the experimental, theoretical, and empirical data now available, isotopic fractionation of vertically moving water as a result of shale micropore filtration is a plausible fractionation mechanism (Huber and others, 1956; Longsworth, 1960; Deve11, 1962; Eyraud and others, 1963; Graf and others, 1965; Hanshaw and Zen, 1965; Hitchon and Friedman, 1969; Coplen, 1970; Coplen and Hanshaw, 1973). Berry and Hanshaw (1960), and Hanshaw and Hill (1969) have suggested that the San Juan basin of New Mexico may exhibit shale-membrane phenomena.

Carbonate cements in outcropping Cretaceous sandstones over the Bisti field display mean $0^{18} / 0^{16}$ values indicating significant depletion in $0^{18}$. The distribution of $\delta \mathrm{C}^{13}$ and $\delta 0^{18}$ values roughly parallels the subsurface facies elements of Sabins (1963) (fig. 7). Relatively low salinity formation waters of $45,000 \mathrm{ppm}$ and an overlying section of interbedded sandstone and shale support the concept of escape of hydrocarbons dissolved in water under an osmotic drive. Not only does salinity have a pronounced effect on hydrocarbon solubility, but the very fact that differences in concentration occur in formation waters on opposite sides of shale membranes indicates differences in chemical potential as a driving force which can move the water through shales in an upward (or downward) direction. Water migrating upward under the influence of chemical potential undergoes isotopic fractionation by shale micropore filtration. Coplen and Hanshaw (1973) experimentally demonstrated with distilled water and $\mathrm{NaCl}$ solution forced through compacted clay that the ultra-filtrate is depleted in both $D$ and $0^{18}$ relative to the residual solution. And, although salts are also retained in the residual solution by shales with membrane properties (McKelvey and Milne, 1962; Hanshaw, 1962; Hanshaw and Coplen, 1973), no additional isotopic fractionation due to a salt filtering mechanism was observed by Coplen and Hanshaw. Vertically moving fractionated water mixes with ground water where isotopic exchange with precipitating diagenetic salts result in $0^{18}$-depleted cements.

Case III: Origin of carbonates with "normal" $0^{18} / 0^{16}$ ratios.--Cropping out over the Cement and Velma oil fields of southern Oklahoma are carbonatecemented sandstones whose isotopic compositions are characteristic of this kind of relatively unrestrained leakage. These types are represented at the apex of the curves in figure 5 and are the interstitial carbonates whose average oxygen isotopic compositions are not anomalous but whose low end-member carbon isotopic contents are peculiarly depleted in $\mathrm{C}^{13}$. These kinds of compositions come about by effusive leakage of hydrocarbons from reservoirs through relatively permeable, poorly compacted, fractured, and faulted roof rocks.

The Cement field is in the southeast Anadarko basin in Caddo and Grady Counties, oklahoma. The field was discovered in 1917. The Cement structure is a northwest-southeast doubly plunging asymmetrical anticline with two distinct domes (East and West Cement). Oil and gas are produced from shallow Permian sandstones and Pennsylvanian carbonates and clastics from depths ranging from 600 to $2,100 \mathrm{~m}$. 

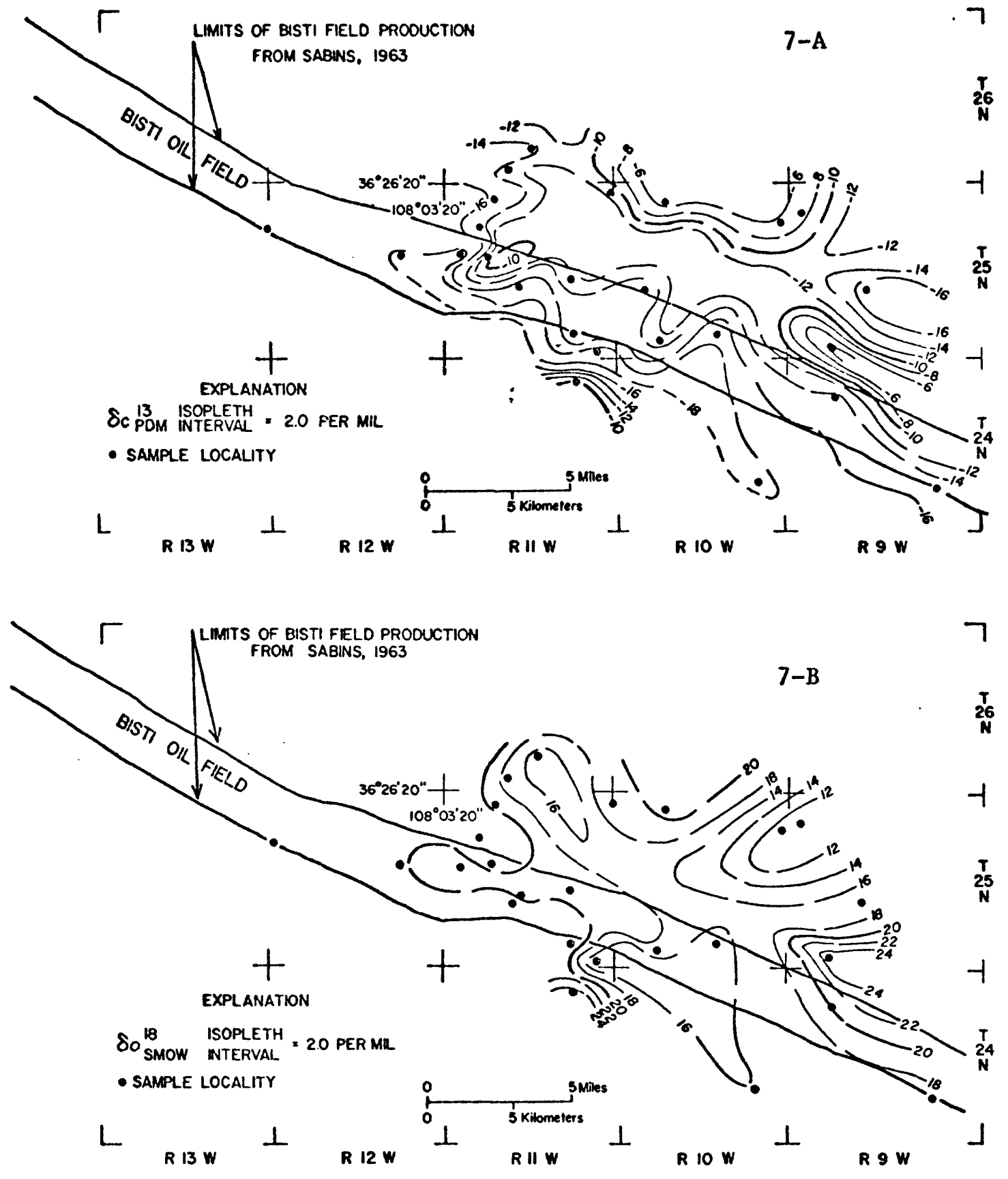

Figure 7.--Sketch maps of the variation of $\delta C^{13}$ (A) and $\delta 0^{18}$ (B) in carbonate cements from surface sandstones cropping out over the Bisti oil field, New Mexico. Unpublished data from R. L. Noble. Isopleth interval $2 / \mathrm{mil}$. 
The steeper northwest flank of the anticline reflects a major reverse fault which trends parallel to the anticline. At the surface, Permian sandstones are unconformably draped over the more intensely folded and faulted pre-Permian section below.

Oils from Cement field have API gravities ranging from $10^{\circ}$ to $36^{\circ}$. Approximately 7,500 hectares have been proven productive. Marked surface alterations have been known at Cement for some time; surface mapping led to the field's discovery (Reeves, 1922; Har1ton, 1960; Hermann, 1961; Halbouty, 1968; Donovan, 1974).

The Velma oil field is located in Stephens County, Oklahoma. Production is from Paleozoic rocks arched in a northwest-southeast doubly plunging faulted anticline located along the axis of the Anadarko geosyncline. The field was discovered by geologic mapping in 1917 and early production of oil and gas from shallow (120-275 m) Permian sandstones. Deep development began in 1941 when a well was drilled to $2,180 \mathrm{~m}$. Predominantly clastic rocks of Pennsylvanian, Mississippian, and Ordovician age are the important pre-Permian oil and gas reservoirs. Oil is produced by a combination of solution gas drive and gravity drainage. The API gravities range (in degrees) from the high $20^{\prime} \mathrm{s}$ to the low 40 's. Low gravity oils are found in the deeper sandstones and in downdip locations. Formation water salinities are highly variable and range from about $20,000 \mathrm{ppm}$ to $90,000 \mathrm{ppm}$. As of 1955 the Velma field had 1,550 producing wells with about 2,750 productive hectares.

Outcropping Permian rocks (red beds) form a mildly arched blanket unconformably overlying the older, more disturbed section. A steeply inclined thrust fault traverses the central part of the anticline, but does not appear to penetrate the overlying Permian section. A prominant topographic ridge, with as much as $100 \mathrm{~m}$ of relief, is the result of differential cementation of sandstones at the surface along the axis of the structure (Borden, 1941; Davis, 1951; Mallory, 1948; Rutledge, 1956; Storm, 1921; Tomilson, 1952).

Evidence for effusion at Cement and Velma is direct: inspissated oil is readily observed in thin sections of surface rocks at both localities (as well as some oil staining observable in the field at Cement) and active oil seeps have been reported at Velma (Gouin, 1956).

Jameson reef and Garza are also interpreted to be mostly representative of this kind of leakage. The Jameson reef field is located in northwest Coke County, Texas. The producing structure is a Pennsylvanian reef on the east side of the Permian (Midland) basin. Production is from approximately 1,970 $\mathrm{m}$ deep. The reef is lenticular, approximately $3.6 \mathrm{~km}$ long and $1.2 \mathrm{~km}$ across at the widest point. Some of the reef highs have as much as $240 \mathrm{~m}$ of subsurface relief. The discovery well was drilled in 1946, and by 1954 the field had reached full development. The producing field covers approximately 8,300 hectares.

The reef mass is enclosed by Pennsylvanian black shales. The reef substrate is a relatively thin $(114 \mathrm{~m})$ limestone. The reef appears to have initially grown as two separate reefs on topographic highs, which subsequently coalesced. Surface mapping and geophysical methods led to the discovery (Ralston and Rettger, 1956; Halbouty, 1968). 
The Garza oil field is located in southwest-central Garza County, Texas, along the northwest edge of the Permian basin. Earlier discoveries at nearby Justiceburg prompted drilling of the Garza discovery well on a local topographic high in 1935. Development proceeded slowly until 1945 when a pipeline outlet was provided for the field.

The structure is an anticlinal fold with several minor domes and saddles with a maximum relief of $40 \mathrm{~m}$. The productive zone is an anhydrite-bearing dolomite of Permian age. Production from this dolomite is from many irregular porous lenses. The producing zone is overlain by red sandstones, shales, and Interbedded anhydrite and salt which in turn are overlain by Triassic "red beds."

The reservoir contains oil and solution gas, and produces by solution drive. The average API gravity of the oil is $36^{\circ}$ (Gardner, 1949; Bailey, 1953).

Important factors in the effusive escape mechanism appear to be the thickness and nature of the overburden and the height of the oil column. Both Cement and Velma fields consist of relatively thick multiple oil reservoirs deformed into high amplitude faulted anticlines unconformably overlain by poorly compacted fine- to coarse-grained rocks. Their formation waters have low TDS, and especially at Cement where the water salinity decreases markedly inversely with depth. This has resulted in vertical transfer of fluids from the deeper to shallower parts of the subunconformity structure by osmotic drive as suggested previously (Donovan, 1974). The thin, poorly compacted overlying rocks were unable to restrain effusive escape of hydrocarbons accumulated in reservoirs at and near the major unconformity. Fresh waters from thermally dehydrated clays in the deeper part of the basin may have played a role in diluting the formation waters at Cement (Donovan, 1974). Once near the surface, $\mathrm{C}^{13}$-impoverished oxidized carbon was incorporated into pore-filling cements. Gas, released from seeping liquid hydrocarbons by depressurization where it locally induced some ground-water evaporation, can account for some high $\delta 0^{18}$ values at both fields.

At least two additional diagenetic processes resulting in special isotopic signatures have been interpreted to occur in rocks over oil and gas accumulations. These are the conversion of calcium sulfate to calcium carbonate by bacteria utilizing escaping hydrocarbons (Thode and others, 1953; Feely and Kulp, 1957; Davis and Kirkland, 1970; Donovan, 1974; Kirkland and Evans, 1976) and the precipitation of diagenetic pore-filling carbonates by salting out of solutes at sand-shale interfaces owing to double layer phenomena (Donovan, 1974). Both products could be useful to explorationists.

Case IV: Origin of carbonates with $0^{18} / 0^{16}$ values resulting from combined process.--Data points which fall on or near the trend line of figure 6 , but between end-members, represent diagenetic carbonates whose isotopic compositions are influenced by the combined effects of the end-member processes (effusionevaporation; effusion-micropore filtration). The relative position along the line indicates the relative importance of the end-member processes. Doyle, Fox-Graham, and Garza fields are examples.

The Doyle structure is a gentle dome about $20 \mathrm{~km}$ north of the major Velma field in the Anadarko basin in Carter County. Approximately $1,500 \mathrm{~m}$ of Permian rocks unconformably overlie the main Pennsylvanian clastic reservoirs. As with 
most of the fields in this region, earliest production was from shallow Permian sandstones. In 1955 there were 186 producing wells at Doyle. A U.S. Bureau of Mines Hempel Analysis 1ists Doyle crude gravity from $1,787 \mathrm{~m}$ at $41^{\circ}$ API. Little has been published about this field.

The gentle topography at Doyle is a surface expression of the subsurface structure. Doyle was discovered by geologic mapping in the early 1900's (Reed, 1910).

Fox-Graham was initially developed as two separate fields in Carter County, Oklahoma, a few kilometers southeast of the larger Velma structure. Discovery wells were dilled in 1915 (Fox) and 1917 (Graham). Later development extended Graham production northward, and since the mid-twenties Fox and Graham have been considered one field. The Fox structure is an irregular domal anticline of low relief separated from the elongated northwest-southeast trending Graham anticline by a deep-seated fault.

About $610 \mathrm{~m}$ of Permian rocks over1ie the main producing zone but the earliest production was from shallow $(75 \mathrm{~m})$ Permian sandstones. The gently folded Permian rocks unconformably overlie a highly faulted, folded, and truncated Pennsylvanian section. Subsequent development has led to significant deeper production from Pennsylvanian sandstones as well as from pre-Pennsylvanian carbonate rocks. API gravities of the oils produced increase with depth, ranging from $19^{\circ} \mathrm{API}$ at $75 \mathrm{~m}$ to more than $40^{\circ}$ at $1,030 \mathrm{~m}$. As of 1955 there were 742 producing wells with about 800 productive hectares.

The area was explored by careful surface mapping; surface seeps were also known in the Graham area (George and Bunn, 1924; Tomilson, 1952; Tomilson and Storm, 1924).

Kettleman Hills North Dome provides another intriguing model for study. The Kettleman Hills oil field is on the west side of the San Joaquin Valley in Fresno, Kings, and Kern Counties, California. Kettleman Hills are part of the foothills of the California Coast ranges. The three domes that make up the hills extend for approximately $50 \mathrm{~km}$ in a northwest-southeast direction and have a width of 8-10 km. North Dome is the largest of three structures aligned en echelon (North, Middle, and South Domes). The structures are asymmetrical; the southeast limb is steepest. At North Dome, approximately 5,500 hectares have been proved productive; surface geology led to the discovery in 1928 .

Miocene sandstone is the major reservoir and there are several productive zones $(1,540-2,410 \mathrm{~m})$. Oil is also produced from Eocene sandstone. The Miocene reservoir had a free gas cap and within the area of this cap, oil has an API gravity of $60^{\circ}$. Outside the gas cap area, the oil produced as an API gravity of $33^{\circ}$ to $37^{\circ}$, but gravities as $10 w$ as $28^{\circ}$ are reported (Galloway, 1943; Halbouty, 1968; McAllister, 1941; Woodring and others, 1940). Formation waters decrease in salinity with decreasing depth (fig. 8).

Figures 8 and 9 display the variation with depth at North Dome of TDS and the $\mathrm{D} / \mathrm{H}$ values of formation waters. The relationships between TDS vs. depth and the isotopic values vs. depth is obvious and important. Figure 10 shows the correspondence between $\delta 0^{18}$ and $\delta D$ of formation waters at Kettleman Hills. Clayton and others (1966) have demonstrated the strong positive correlation 


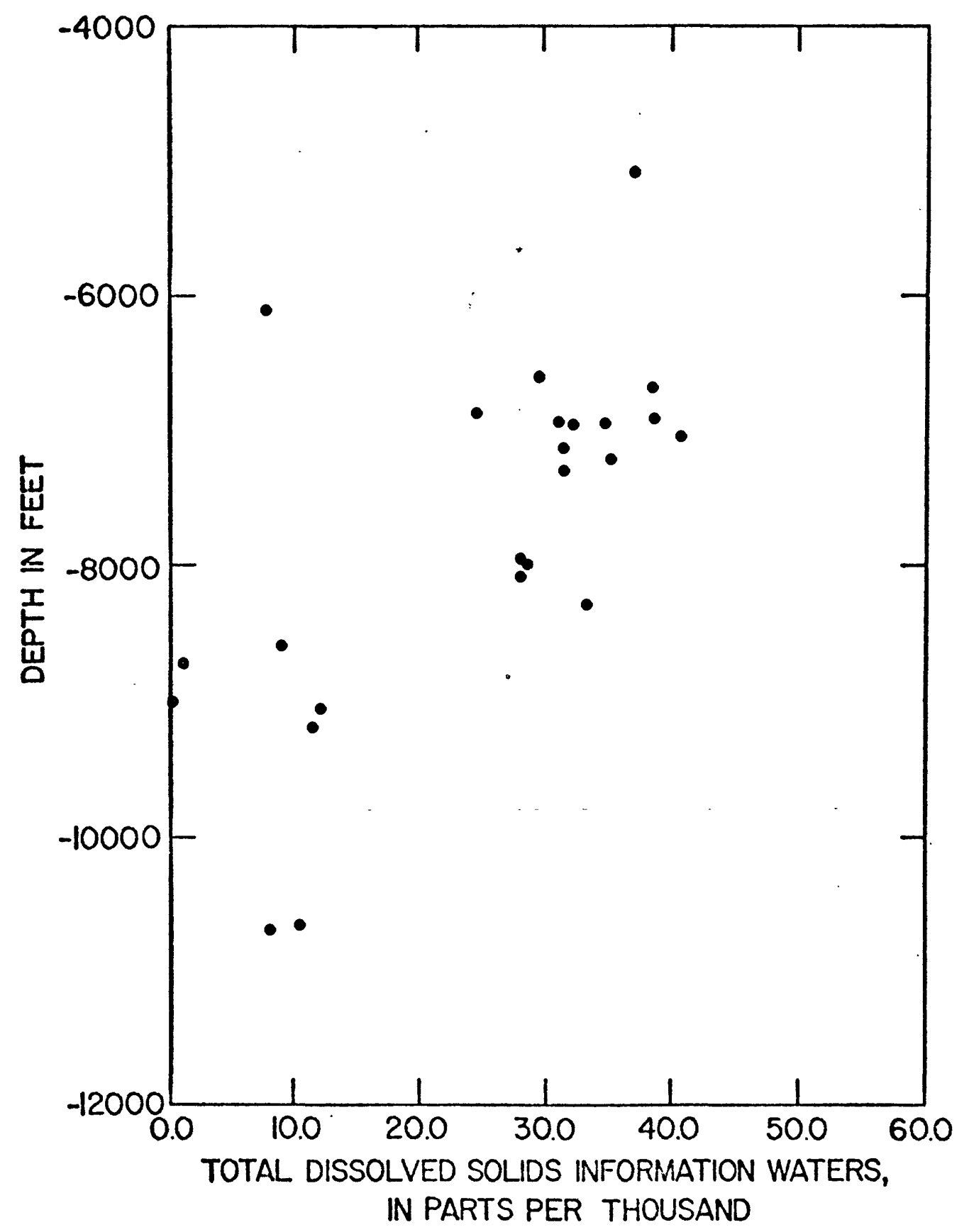

Figure 8.--Variation with depth of total dissolved solids in formation waters, Kettleman Hills, North Dome, California. Data from Kharakra and others (1973). 


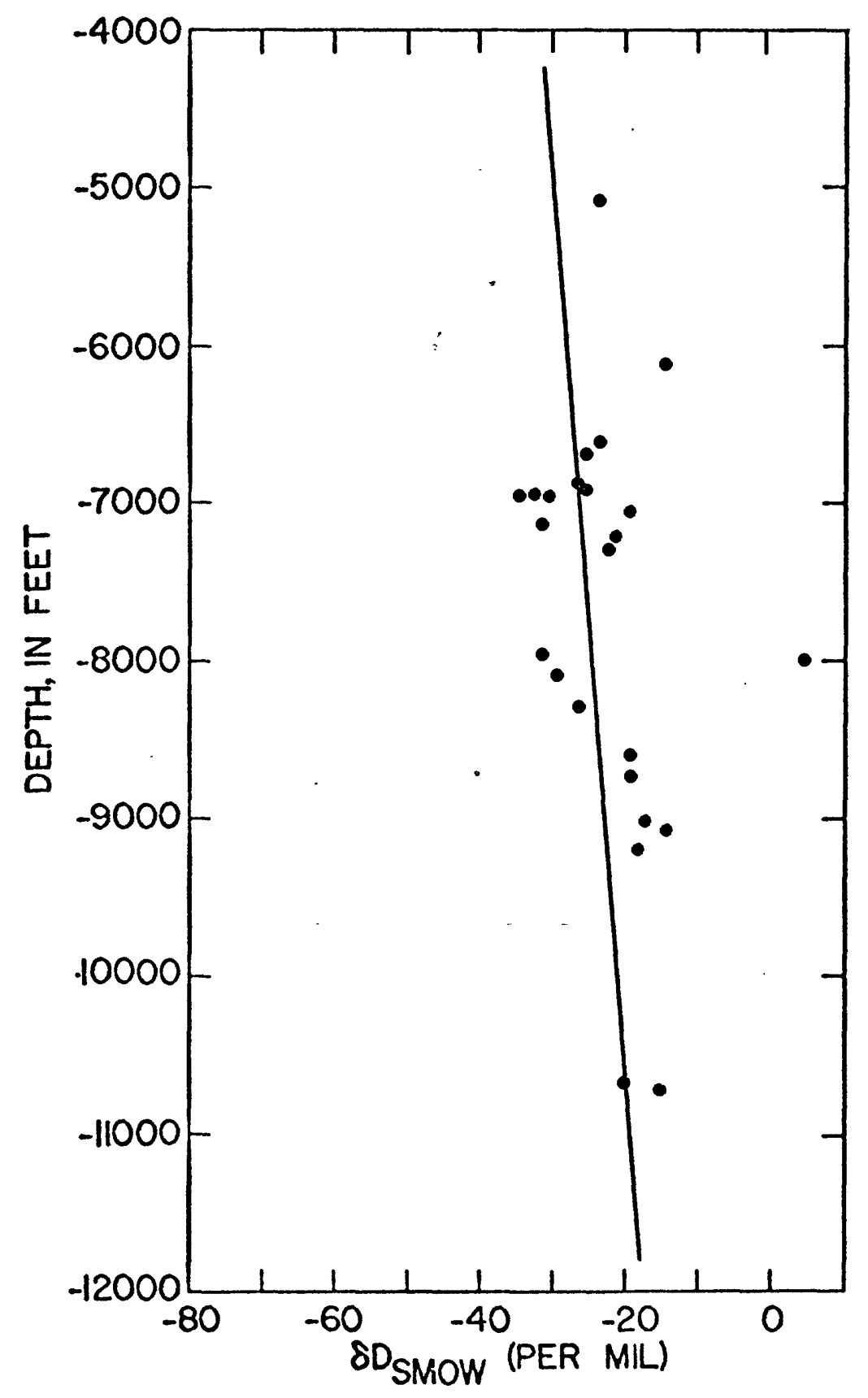

Figure 9.--Variation with depth of $\delta D$ of formation waters, Kettleman Hills, North Dome, California. Data from Kharaka and others (1973). 


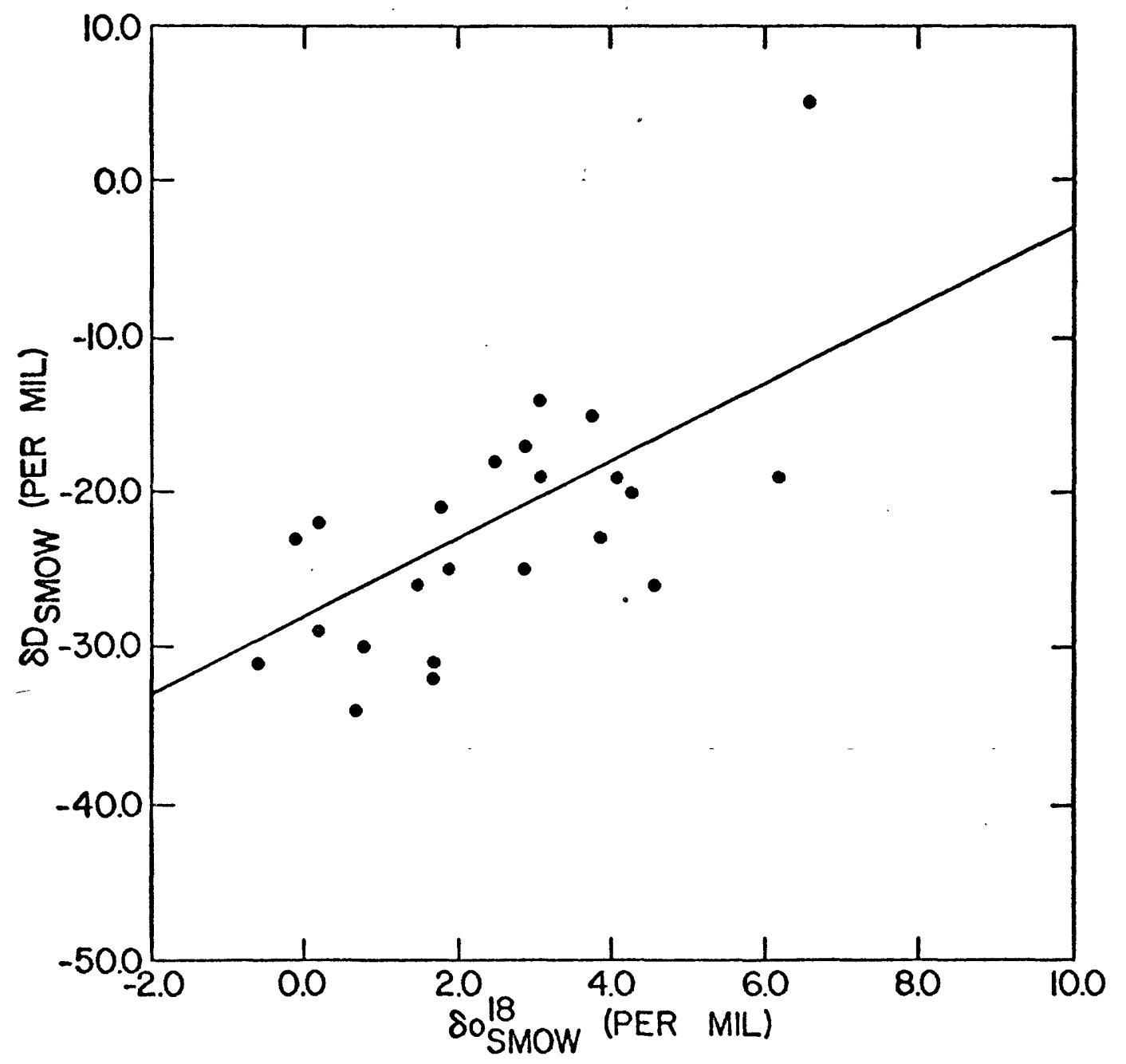

Figure 10.--Relation between $\delta 0^{18}$ and $\delta D$ values for formation waters, Kettleman Hills, North Dome, California. Data from Kharaka and others (1973). 
between $\delta 0^{18}$ of water and salinity; an inverse relationship is indicated by the Kettleman Hills data. The Clayton and others pioneer work also showed that the $D$ content of formation waters is not greatly altered by exchange processes. The Kettleman Hills fluid data strongly suggest that shale micropore filtration operates there which causes a regular depletion in $D$ and $0^{18}$ from formation waters with decreasing depth. This process is sufficiently potent and rapid to override oxygen exchange effects between water, rocks, and dissolved solids.

The trend of decreasing salinity with increasing depth has special significance for it implies osmosis may be at work. Transfer of water from the dilute to the concentrated side of a shale membrane is also effective in transferring dissolved hydrocarbons, especially the non-polar n-alkanes. For even though the polar hydrocarbons are more soluble in water than are non-polar ones, their polarity inhibits their effective passage in solution through the shale membranes because they are filtered at the double layer along with the charged species. This accounts in part for the increased paraffinicity of crudes with decreasing depth commonly observed in fields where salinity decreases with increasing depth (fig. 11; Donovan, 1974, figs. 13 and 14).

In addition to shale micropore filtration, another driving mechanism is suggested by the southwest-northeast cross section through the Kettleman Hills region (fig. 12). The deeper Miocene reservoirs of North Dome crop out several miles to the southwest at Reef Ridge in the Kreyenhagen Hills where they are relatively steeply dipping and ideally positioned for meteoric-water recharge. Where water, under hydrodynamic pressure from recharge areas in the Kreyenhagen Hills, flows through the intervening Kettlemar Plains syncline into the North Dome anticline, a vertical component of the flow vector may result. This would add a hydrodynamic driving force to the chemical driving force.

Study of the isotopic data from Kettleman Hills North Dome rocks suggests a history of two opposing fractionation processes. The mean $\delta 0^{18}$ value of $25.2 / \mathrm{mil}$ of calcite cements is somewhat less than the theoretical value of $27.7 / \mathrm{mil}$ in keeping with the evidence that vertically moving waters were fractionated. Some samples taken over the anticline are $0^{18}$-enriched and are also depleted in $\mathrm{C}^{\mathrm{l} 3}$. A pronounced gravity segregation of hydrocarbons has resulted in free gas and $60^{\circ}$ API gravity oil with gas/oil ratios as high as $80,000 \mathrm{ft}^{3} /$ barrel being restricted to the apical region of North Dome (Galloway, 1943). Thus significant amounts of gas probably have escaped the reservoirs with other fluids, and gas-induced evaporation of ground water has resulted in localized $0^{18}$ enrichment. The isotopic data for fossil shells, from outcropping Pliocene and Pleistocene sandstones along the North Dome anticline indicates that those materials have compositions reflecting the environment in which they grew (Stanton and Dodd, 1970; Dodd and Stanton, 1975) and that they have not undergone significant isotopic exchange during diagenesis (table 2). Hence, the differences between the composition of the fossils and the pore-filling carbonates described here permits a fortuitous comparison between depositional and late diagenetic environments.

A hydrodynamic driving mechanism is also postulated for the Gunbarrel Hill region of Colorado on the east flank of the Denver basin. Here, rocks stratigraphically equivalent to local petroleum reservoirs, crop out along the Front Range of the Rocky Mountains. 


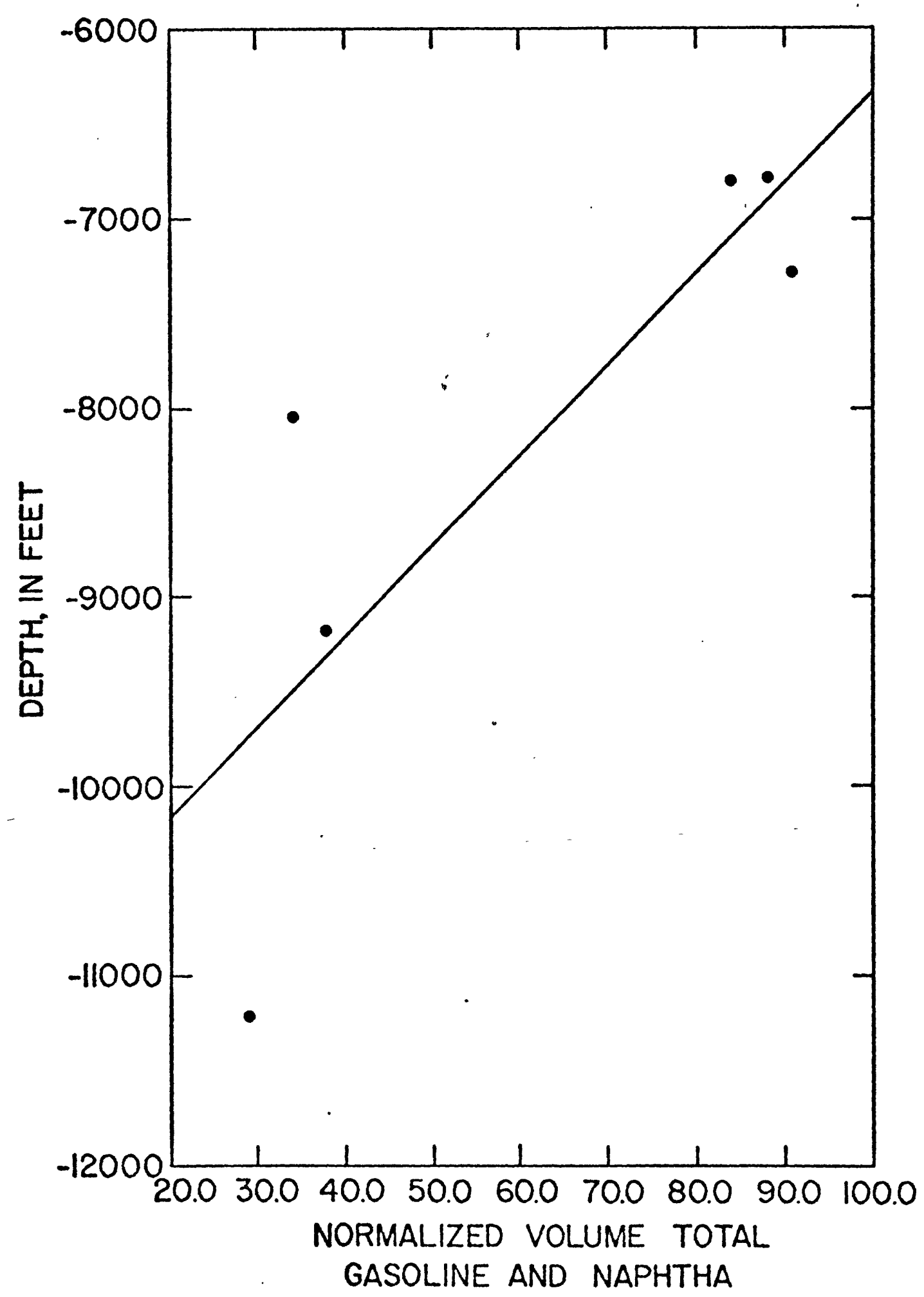

Figure 11.--Variation with depth of the normalized volume of Tota1 Gasoline and Naphtha $(\mathrm{TG}+N)$ in crude oils, Kettleman Hills, North Dome, California. Data from U.S. Bureau of Mines. 


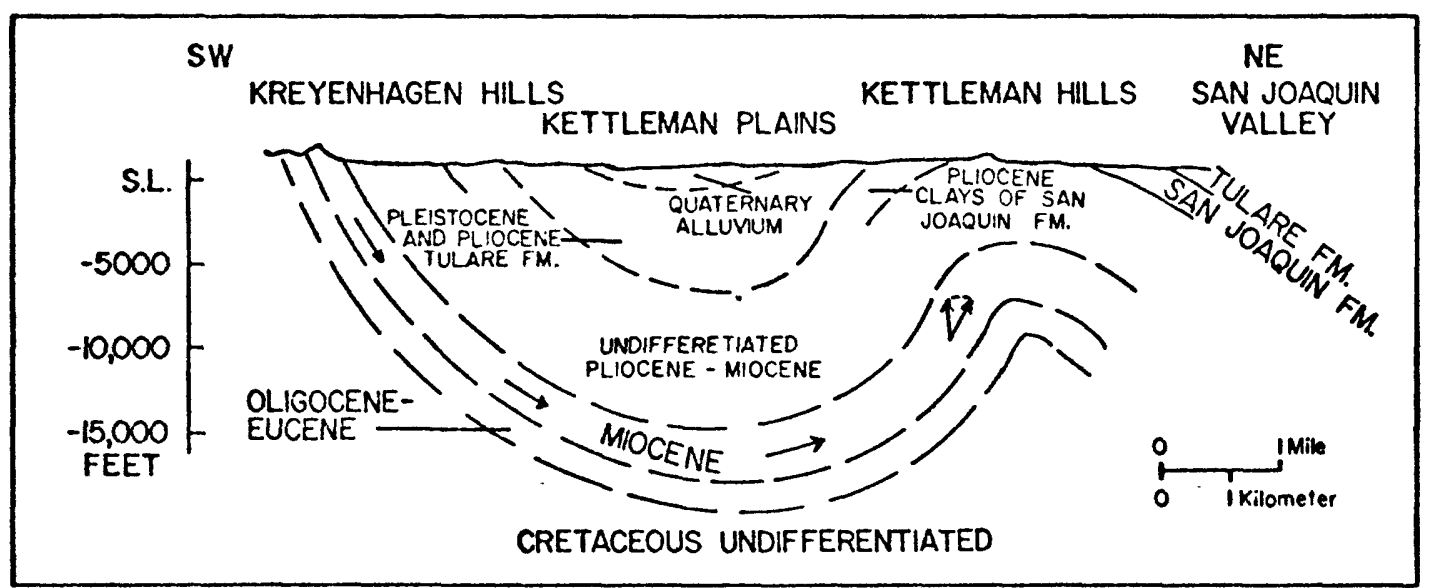

Figure 12.--Northeast-southwest cross section through Kettleman Hills, North Dome. Modified from Galloway (1943). Hypothetical flow vectors added with vertical component resolved in core of anticline. 
The Gunbarrel Hill anomaly is in Boulder and Weld Counties, Colorado, on the west flank of the Denver basin. The Denver basin has long been a prolific oil and gas province. Geochemical prospecting has pinpointed several areas of color change and mineralization in the Cretaceous surface rocks, suggesting that leakage from a hydrocarbon reservoir may have taken place. Neighboring fields in the area include the Boulder oil field, the Wattenburg gas field, and the Spindle oil field. The Gunbarrel anomaly may overlie an extension of the Spindle field, a stratigraphic accumulation located a few kilometers to the east. About $20 \mathrm{~km}^{2}$ are considered prospective (Donovan, Noble, and others, 1975; Roberts and others, 1976).

Gunbarrel Hill is formed by gently eastward dipping carbonate-cemented rocks. The outcropping Cretaceous sandstones are partially obscured by remnants of Pleistocene alluvial terranes. Oil and gas in nearby fields is produced from Upper and Lower Cretaceous rocks.

Ground-water recharge in this area tends to flush most reservoirs. Where oil saturations are high and where the driving force is small, the force is not sufficient to overcome relative permeability differences between oil and water. We speculate that a vertical vector component in the hydrodynamic drive of the moving dilute waters captures minute amounts of hydrocarbons by dissolution at the edge water interface and remobilizes them; bypass flow occurs around the edges of the reservoir and when the micropore filtered waters interact with precipitating carbonates at the surface, halo-shaped anomalies result which ring the vertical projection of the subsurface accumulation. In reality, such halos or aureoles are more commonly incomplet: or crescent-shaped, with maximum development along the edge of the accumulation opposing the direction of subsurface flow.

\section{Chemical Data}

The weathering of iron-bearing minerals releases ferrous iron. Normally this iron is oxidized to ferric iron by oxygen dissolved in soil waters whereupon it commonly hydrolyzes and precipitates in a variety of ferric oxides. These oxides are stable in the oxidizing zone where they color sediments and rocks vivid yellows through oranges to pinks and reds. In reducing environments, however, the relatively soluble ferrous iron in the absence of oxygen remains in solution where it is available for transport. Under these conditions, continued loss of iron through dissolution and removal in water results in rocks which appear markedly "bleached" or tinted. Iron oxides from previous weathering cycles are unstable in reducing environments and, undergoing reduction, their iron is subsequently also dissolved. Hematite may be reduced to magnetite or maghemite. Additionally, in the presence of $\mathrm{H}_{2} \mathrm{~S}$, pyrite may be precipitated. Reducing conditions in rocks over oil deposits can be caused by seeping hydrocarbons and associated compounds such as hydrogen sulfide. A qualitative measure of the intensity of reduction that has taken place in the rocks is furnished by systematic color change from dark red hues in peripherally unaltered strata to yellows and whites at central localities. This is true only for noncemented or weakly cemented (permeable) rocks.

Carbonate cements which strongly impregnate rocks result from relatively rapid and intensive processes of precipitation and tend to be collectors of both iron and manganese in ionic substitution; effective chemical separation of 
elements such as iron and manganese owing to slight differences in redox potential and solubility is precluded.

Manganese's chemical nature is similar to iron's and it is mobilized In a similar fashion. Over some oil fields carbonate cements are enriched in both manganese and iron whereas over others, the cements display decreased iron content with increased manganese (figs. 13 and 14). Slow increase in pH result in dissolved iron compounds reaching solubility limits before manganese compounds; rapid changes result in co-precipitation. Manganese precipitates as carbonate (or as we suggest here, substituted for other cations in other carbonates if only small amounts are present) as the ground water slowly increases $\mathrm{pH}$ or if the environment is or becomes reducing. Thus separation from iron is due to differences in solubility and oxidation potential (Krauskopf, 1957). We have implied in the discussion of $0^{18} / 0^{16}$ fractionations that large fractionations may indicate rapid processes whereas small fractionations may come about slowly. A plot of $\log \mathrm{Mn} / \mathrm{Fe}$ vs. $\delta 0^{18}$ for the weakly cemented rocks at Gunbarrel Hill suggests that the separation processes may have operated there, albeit, inefficiently (fig. 14). However, we caution against too much reliance upon such plots as figures 13 and 14 , as the mapped distribution pattern of such variations is equally or more important.

Laboratory measurements on carbonate cemented rocks before and after acid digestion indicate that the great preponderance ( $>90 \%$ ) of manganese is incorporated in the carbonate lattice. Figure 15 suggests that manganese is concentrated in cements resulting from both the micropore filtration and gasinduced evaporation end-member processes because manganese appears to increase as the $0^{18} / 0^{16}$ ratio increases or decreases from a $\delta 0^{18}$ minimum of about 20-25 per mil. A total of 207 data points from oil field areas tabulated in tables 2 and 3 as well as a few spot samples from two additional oklahoma fields not tabulated were used (Carter-Knox and Cruce). Figure 16 is a map of the carbonateheld manganese within the carbonate-cemented areas at Cement field. Manganese concentrations range through an order of magnitude in a systematically mappable way. Background values in non-carbonate cemented rocks average only a few hundred ppm. Figure 17 shows the manganese concentrations in soils overlying the field; the values tend to be lower and the isopleth pattern is broader and more attenuated in soils than in bedrock, but the presence of high manganese values at crestal localities persists. Similar relationships may hold for other elements but they have not been worked out by us at this writing.

\section{SUMMARY}

This paper describes some mechanisms whereby hydrocarbons may escape entrapment, migrate to the surface, react chemically with dissolved constituents in ground waters, and leave residual evidence in surface rocks and soils. The mechanisms include escape of hydrocarbons by effusion, solution, and diffusion. Meteoric water and its cycle play an important role in the overall processes and especially in mobilizing the more soluble light ends of crude oil. Gasinduced evaporation of ground water and micropore filtration of vertically moving formation water can cause isotopic fractionations, evidence of which is retained in pore-filling carbonate cements. Iron and manganese, mobilized in reducing environments caused by the presence of seeping hydrocarbons or their associated compounds, appear to be systematically concentrated in carbonate cements in rough proportion to the intensity of microseepage as interpreted 


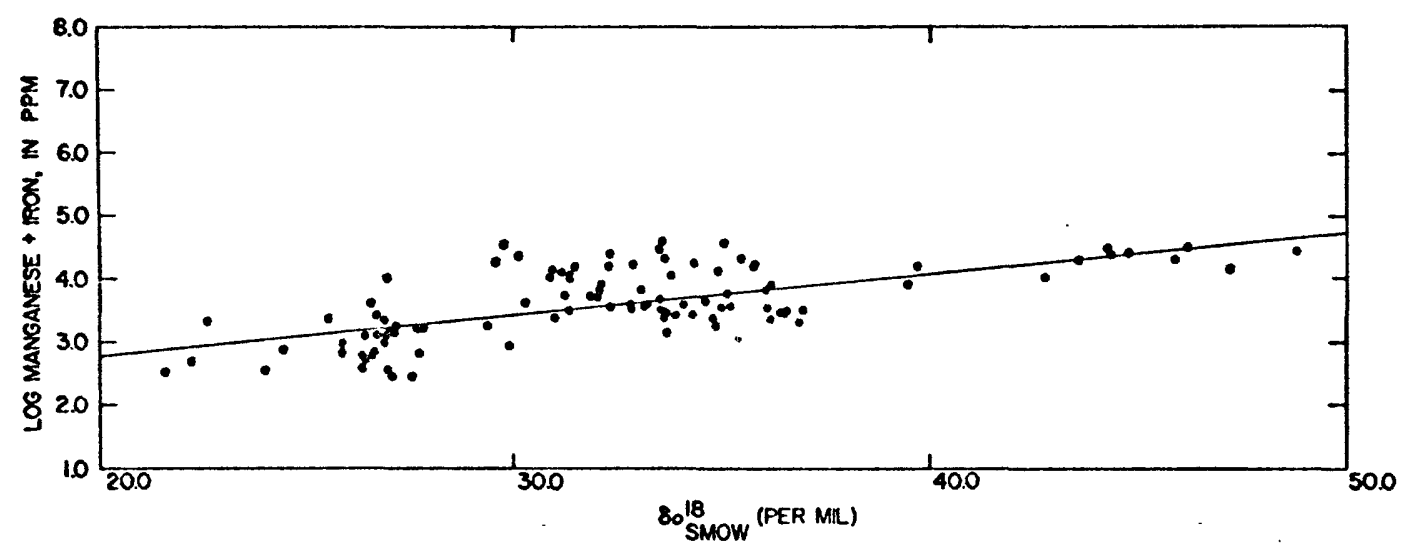

Figure 13.--Relation between iron and manganese and $\delta 0^{18}$ for carbonate cements in sandstones cropping out over Fox-Graham, Doyle, and Davenport oil fields, Oklahoma. 


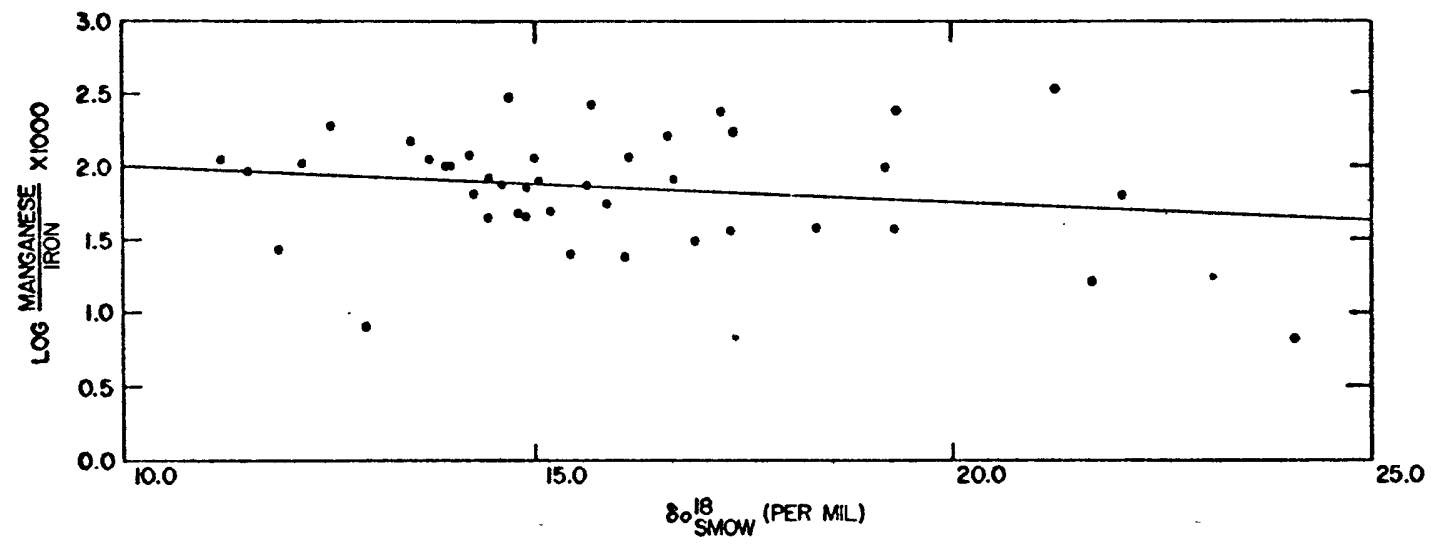

Figure 14.--Relation between total $\mathrm{Mn} / \mathrm{Fe}$ and $\delta 0^{18}$ for calcitecemented sandstones, Gunbarrel Hill, Colorado. Data from Donovan, Noble, and others (1975). 


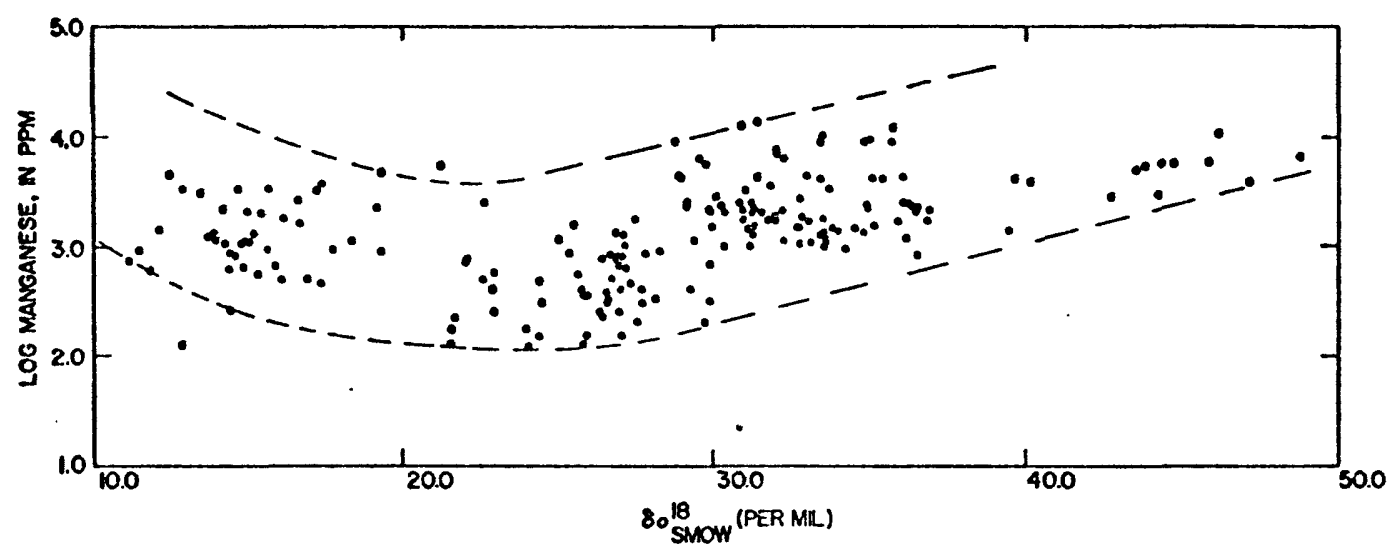

F1gure 15.--Relation between manganese and $\delta 0^{18}$ for 207 outcropping carbonate cemented sandstones from various oil field areas. Ninety-nine percent of all points lie within dashed lines. 


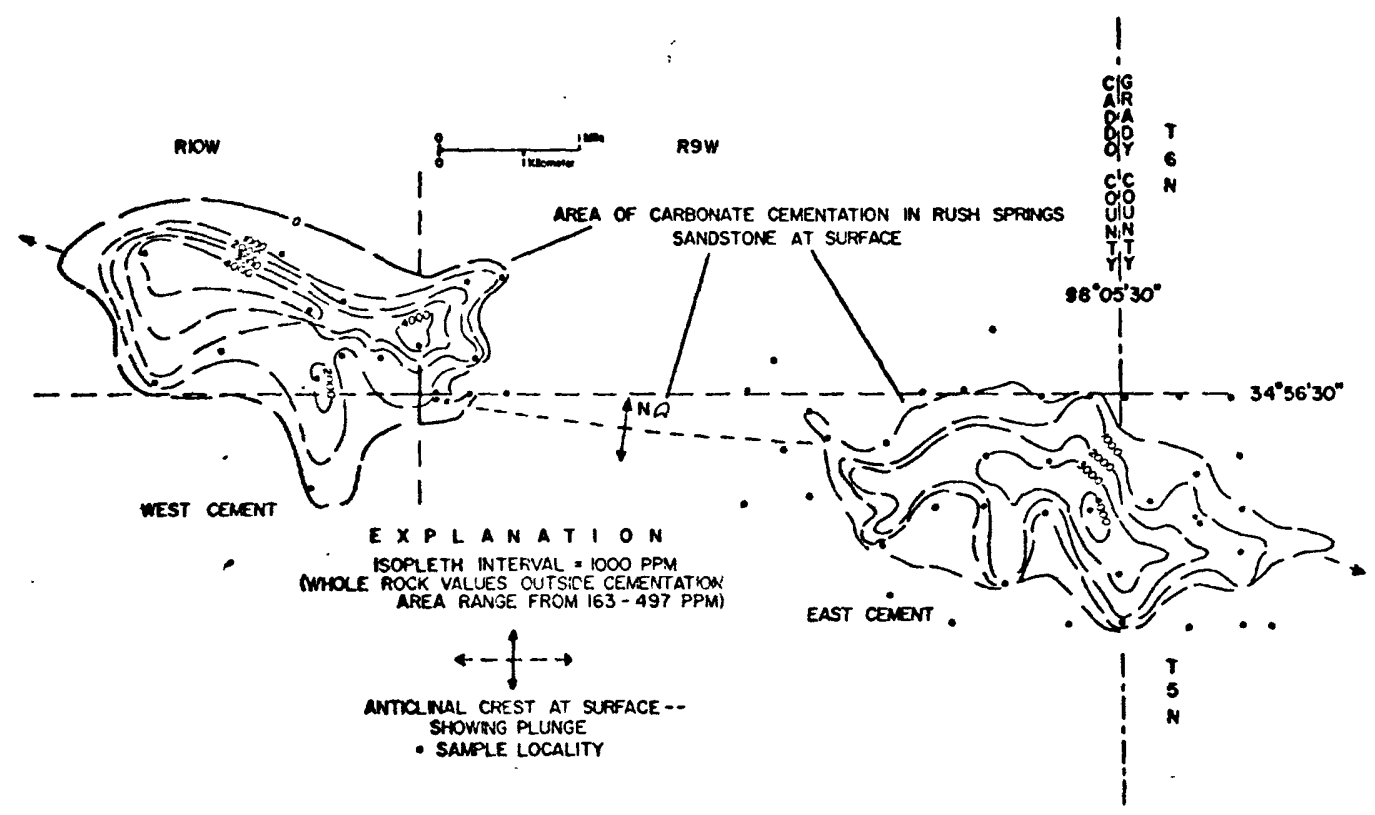

Figure 16.--Variation of manganese held in carbonate cements of outcropping sandstones, Cement oil field, Oklahoma. Isopleth interval $1,000 \mathrm{ppm}$. 


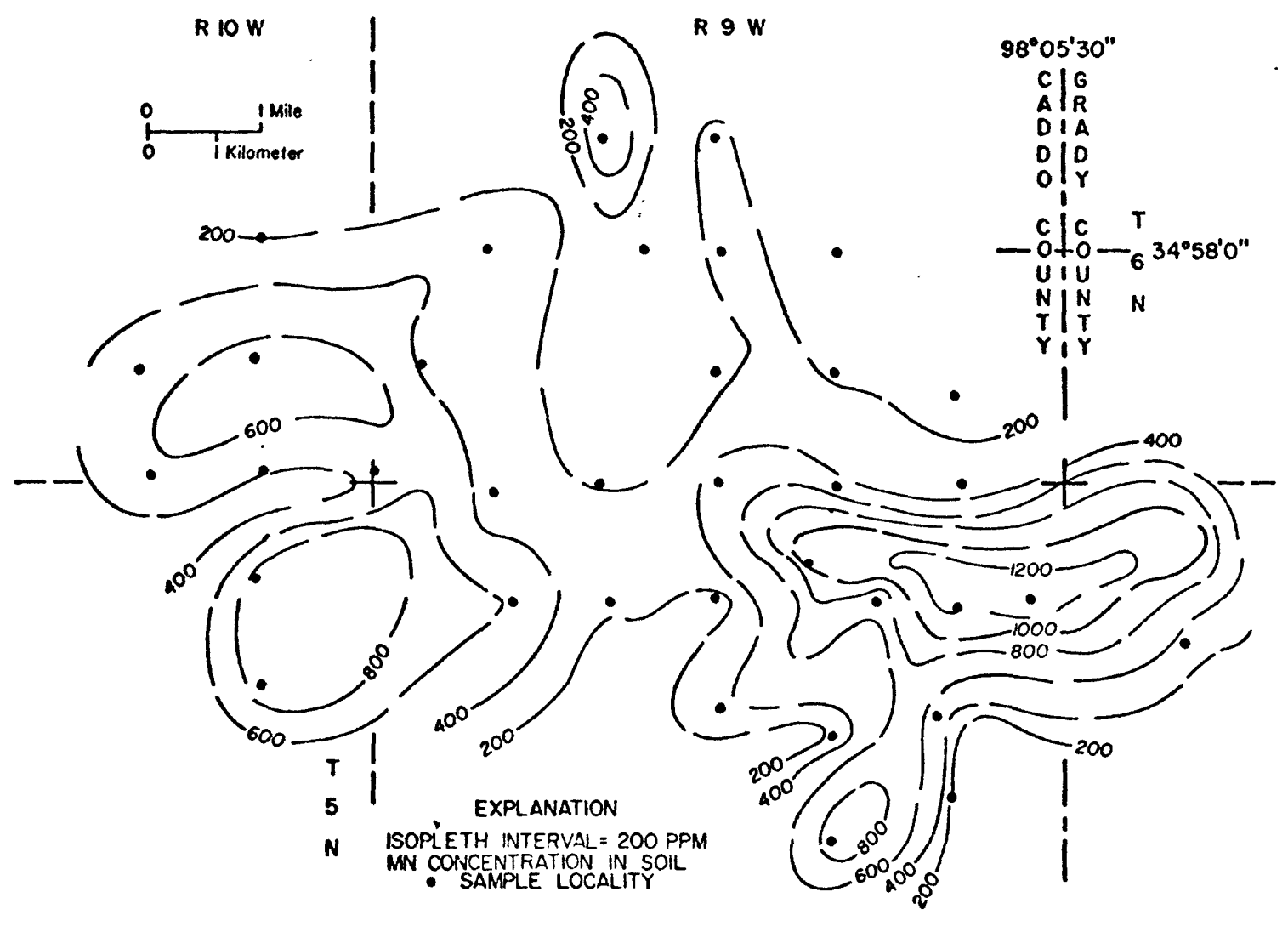

Figure 17.--Variation of manganese concentration in soils, Cement oll fleld, Oklahoma. Isopleth iterval 200 ppm. 


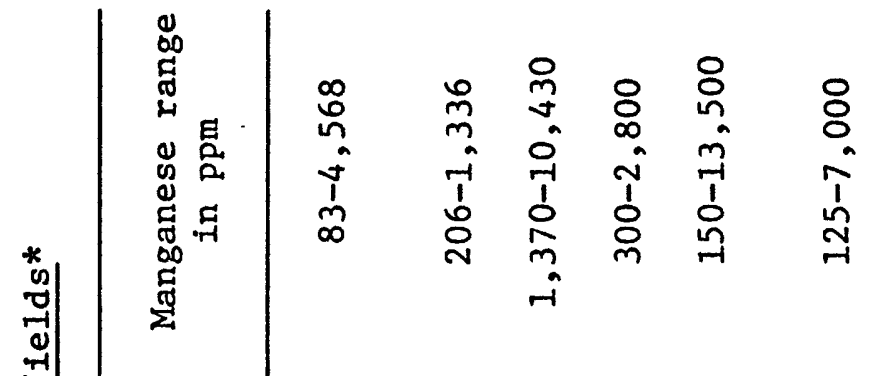

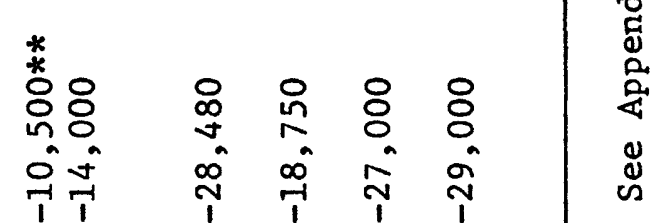

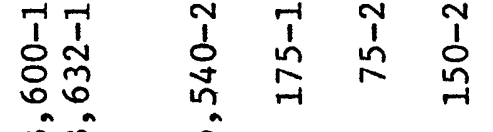

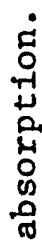

嵌

공

苞

$\mid \begin{aligned} & \text { ปै } \\ & \text { ơ }\end{aligned}$

r

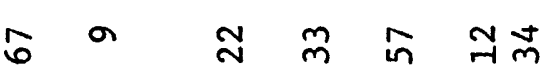

过

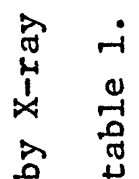

感

苋

落

尊

宛

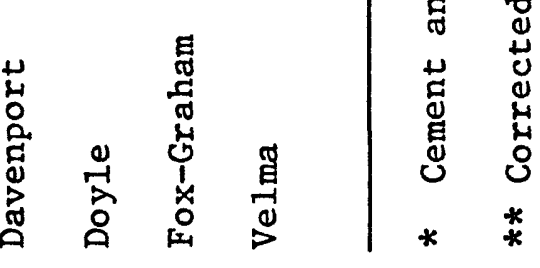


from oxygen isotopic fractionation of ground waters. We stress here, also, that the full impact of microbial processes cannot be evaluated from the field data alone.

The model is schematic; obviously the real mechanisms are infinitely more complex and interactive, but the concepts proposed can serve as a geochemical basis for prospecting for oil and gas deposits. Certain chemical properties of surface rocks are strongly influenced by petroleum microseepage and can be investigated by both ground geophysical and remote measurement. These include such things as iron content, the iron's oxidation state, and carbonate mineralization. For example, detailed gravimetric surveys could isolate near surface variations in mass arising from localized late diagenetic mineralization (Elkins, 1951, p. 48-49; Ralston and Rettger, 1956; McCu1loh, 1969). In addition, such mineralization conceivably could result in telluric current anomalies (Yungul and others, 1973). The spectral reflectivity of rocks is greatly influenced by the amount of iron present and its oxidation state (Hunt and Salisbury, 1970; Hunt and others, 1971; Goetz, 1975) which in turn suggest orbital and airborne multispectral imaging and image enhancement techniques. Manganese contributes to the natural luminescence of calcites in a systematic way, enabling airborne fluorometric measurement and anomalous distributions of other elements in soils are amenable to rapid airborne sampling (Donovan, Barringer, and others, 1975). Preliminary work by us suggests that the near surface reduction of hematite to magnetite may be sufficient over some oil fields to enable detection by aeromagnetic methods. Remote sensing techniques are especially attractive because they are cost effective (Craib, 1972); Maxim and Cullen, 1977).

\section{ISOTOPIC AND CHEMICAL ANALYSES}

\section{Isotopic Data}

Calcareous samples were collected from outcrops over oil fields. In general, the limited distribution of outcrops governs sampling locations and density. In the laboratory, samples were split, crushed to powder, then Xrayed to determine the proportions of calcite versus dolomite in the porefilling cements or replacement materials. Powdered samples were placed in reaction flasks with 100 percent $\mathrm{H}_{3} \mathrm{PO}_{4}$ at $25^{\circ} \mathrm{C}$ for at least four hours and isotopic measurements were made on the $\mathrm{CO}_{2}$ evolved with a Nier type of massspectrometer. The isotopic analyses are reported here in the $\delta$ terminology:

$$
\delta=\frac{\mathrm{R}_{(\text {sample) }}-\mathrm{R} \text { (standard) }}{\mathrm{R}(\text { standard })} \times 1,000,
$$

where $\mathrm{R}=$ Ratio $=\mathrm{C}^{13} / \mathrm{C}^{12}$ or $0^{18} / 0^{16}$. Our standards are the Chicago PDB standard for carbon and Standard Mean Ocean Water (SMOW) for oxygen. The analytical procedures are those of McCrea (1950), Craig (1957), and Epstein, Graf, and Degens (1964). The $\delta$ values are reported to ${ }_{-0.1} / \mathrm{mil}(2 \delta)$, and the dolomite analyses are corrected for the acid fractionation factor (Sharma and Clayton, 1965).

Isotopic ranges and means are tabulated in table 2 and the data are also displayed in a series of plots (figs. 5, 6, 9, and 10) and maps (fig. 7). 
Allen and Matthews (1977), concerned with small ranges in isotopic values, have questioned the "resolving power" of plotting "typical" limestone ranges (fig. 5). However, we suggest that Murata and others (1969) boundaries of typical limestone ranges, encompassing many points from over the world, emphasize the abnormal nature of our materials.

\section{Chemical Data}

Iron and manganese contents of samples were measured either by X-ray fluorescence (XRF) in the laboratory using the analytical technique described by Adler (1966) with a Picker X-ray unit or by atomic absorption spectrophotometry (AA) in a mobile field laboratory using analytical techniques described by the Perkin-Elmer Corporation (1973). The latter unit used is Perkin-Elmer Model 360. The X-ray analyses are considered accurate to +10 percent and the atomic absorption data are considered accurate to +1.0 percēnt. Whole rock analyses on finely powdered samples were made with $X \bar{R} F$ techniques, and $A A$ techniques were employed on diluted residual solutions following complete HCl acid digestion of weighed and powdered carbonate-cemented samples. All analytical data are reported in parts per million (ppm). 


\section{REFERENCES CITED}

Adler, Isadore, 1966, X-ray emission spectrography in geology: New York, Elsevier Publishing Co., 285 p.

Allan, J. R., and Matthews, R. K., 1977, Carbon and oxygen isotopes as diagenetic and stratigraphic tools--surface and subsurface data, Barbados, West Indies: Geology, v. 5, no. 1, p. 16-21.

Andreev, P. F., Bogomolov, A. I., Dobryanskii, A. F., and Kartsev, A. A., 1968, Transformation of petroleum in nature: Internat. Series Monographs Earth Sci., v. 29,466 p.

Bailey, N. J. L., Jobson, A. M., and Rogers, M. A., 1973, Bacterial degradation of crude oil--comparison of field and experimental data: Chem. Geology, v. 11, p. 203-221.

Bailey, N. J. L., Krouse, H. R., Evans, C. R., and Rogers, M. A., 1973, Alteration of crude oil by waters and bacteria--evidence from geochemical and isotope studies: Am. Assoc. Petroleum Geologists Bull., v. 57, p. 1276-1290.

Bailey, P. T., 1953, The development and history of the Garza Field, Garza County, Texas: Lubbock, Texas, Texas Technological College, M.S. thesis, $62 \mathrm{p}$.

Baker, E. G., 1969, A geochemical evaluation of petroleum migration and accumulation, in Nagy, B., and Colombo, W., eds., Fundamental aspects of petroleum geochemistry: New York, E1sevier, p. 299-329.

Barton, D. C., 1927, The indications of the oilfield in the mid-continent and gulf coastal plain of the United States: Jour. Inst. Petrol. Technology, v. 13, p. 333-339.

Barton, W. H., 1934, National history of gulf coast oil, in Wrather, W. E., and Lahee, F. H., eds., Problems of petroleum geology: Tulsa, Okla., Am. Assoc. Petroleum Geologists, p. 109-155.

Berry, F. A. F., 1959, Hydrodynamics and geochemistry of the Jurassic and Cretaceous Systems in the San Juan basin, northwestern New Mexico and southwestern Colorado: Stanford Univ., Ph. D. thesis, $213 \mathrm{p}$. 1969, Relative factors influencing membrane filtration effects in geologic environments: Chem. Geology, v. 4, p. 295-301.

Berry, F. A. F., and Hanshaw, B. B., 1960, Geologic evidence suggesting membrane properties of shales [abs.]: Internat. Geol. Cong., 21st, Copenhagen, 1960, Repeat Session, Norden, p. 209.

Bohon, R. L., and Claussen, W. F., 1951, The solubilities of aromatic hydrocarbons in water: Am. Chem. Soc. Jour., v. 73, p. 1571.

Borden, Joseph L., 1941, Developments in Oklahoma in 1941: Am. Assoc. Petroleum Geologists Bul1., v. 26, no. 6, p. 1058-1072.

Boyle, R. W., and Garrett, R. G., 1970, Geochemical prospecting--A review of its status and future: Earth-Sci. Rev., v. 6, p. 51-75.

Brandenthaler, R. R., Scalter, K. C., and Kent, H. M., 1926, Engineering report on the Davenport oil field, Lincoln County, Oklahoma: Washington, U.S. Bureau of Mines, $48 \mathrm{p}$.

Bredenhoeft, J. D., Blyth, C. R., White, W. A., and Maxey, G. B., 1963, Possible mechanism for concentration of brines in subsurface formations: Am. Assoc. Petroleum Geologists Bull., v. 47, p. 257-269.

Brooks, B. T., 1949, Active-surface catalysts in formation of petroleum-II: Am. Assoc. Petroleum Geologists Bull., v. 33, p. 1600-1612.

Cheney, E. S., 1964, Stable isotopic geology of the Gas Hills Uranium District, Wyoming: Yale Univ., Ph. D. thesis, 342 p. 
Clayton, R. N., 1961, Oxygen isotope fractionation between calcium carbonate and water: Jour. Chem. Physics, v. 34, p. 724-766.

Clayton, R. N., Friedman, J., Grof, D. L., Mayeda, T. K., Meents, W. F., and Shimp, N. F., 1966, The origin of saline formation waters: Jour. Geophys. Research, v. 71, p. 3869-3882.

Coomber, S. E., 1938, Surface indications of oil, in The science of petroleum: London, Oxford University Press, v. 1, p. 291-293.

Coplen, T. B., 1970, Isotopic fractionation of water by ultrafiltration: Univ. Chicago, Ph. D. thesis, $96 \mathrm{p}$.

Coplen, T. B., and Hanshaw, B. B., 1973, Ultrafiltration by a compacted clay membrane; I.--oxygen and hydrogen isotopic fractionation: Geochim. et Cosmochim. Acta, v. 37, p. 2295-2310.

Craib, K. B., 1972, The cost-effectiveness of high altitude systems for regional resource assessment, in Shahrokhi, F., ed., Remote sensing of Earth resources, Conf. on Earth Resources Observation and Information Analysis Systems, March 13-14, 1972: Univ. Tennessee, Space Inst., p. 315-337.

Craig, Harmon, 1957, Isotopic standards for carbon and oxygen and correction factors for mass spectrometric analysis of carbon dioxide: Geochim. et Cosmochim. Acta, v. 12, p. 133-149.

Dansgaard, W., 1964, Stable isotopes in precipitation: Tellus, v. 6, p. 436468.

Davis, J. B., 1967, Petroleum microbiology: Amsterdam, E1sevier, 604 p.

Davis, J. B., and Bray, E. E., 1969, Analysis of oil and cap rock from Challenger (Sigsbee) Knoll, in Initial reports of the Deep Sea Drilling Project: Washington, U.S. Govt. Printing Office, v. 1, p. 415-500.

Davis, J. B., and Kirkland, D. W., 1970, Native sulfur deposition in the Castile Formation, Culberson County, Texas: Econ. Geology, v. 65, p. 107-121.

Davis, W. B., 1951, A study of the Dorhick Hills-Springer sand reservoir of the Velma Poo1, Oklahoma: Am. Inst. Mining Metall. Engineers Trans., v. 192, Tech. Paper 2999, p. 29.

DeGolyer, Everett, 1940, Direct indications of the occurrence of oil and gas, in Elements of the petroleum industry: Am. Inst. Mining Meta11. Engineers, p. 21-25.

DeSitter, L. U., 1947, Diagenesis in oil-filed brines: Am. Assoc. Petroleum Geologists Bul1., v. 31, p. 2030-2040.

Deve11, Lennart, 1962, Measurements of the self-diffusion of water in pure water, $\mathrm{H}_{2} \mathrm{O}-\mathrm{D}_{2} \mathrm{O}$ mixtures and solutions of electrolytes: Acta Chemica Scandinavica, v. 16, p. 2177-2188.

Devlin, F. J., and Tomkins, J. Q., 1957, The Bisti Area, San Juan County, New Mexico: Four Corners Geol. Soc. Guidebook, p. 152-154.

Dickey, P. A., 1966, Patterns of chemical composition in deep subsurface waters: Am. Assoc. Petroleum Geologists Bu11., v. 50, p. 2472-2478.

Dodd, J. R., and Stanton, R. V., Jr., 1975, Paleosalinities within a Pliocene Bay, Kettleman Hills, Calif., in A study of the resolving power of isotopic and funal techniques: Geol. Soc. America Bull., v. 86, p. 51-64.

Donovan, T. J., 1974, Petroleum microseepage at Cement, Oklahoma-evidence and mechanism: Am. Assoc. Petroleum Geologists Bull., v. 58, p. 429-446.

Donovan, T. J., Barringer, A. R., Foote, R. S., and Watson, R. D., 1975, Low altitude remote sensing experiments at Cement and Davenport oil fields, Oklahoma [abs.]: Soc. Explor. Geophysicists 45th Ann. Mtg., Abstracts, Denver, Colorado, 1975, p. 68-69.

Donovan, T. J., Friedman, I., and Gleason, J. D., 1974, Recognition of petroleumbearing traps by unusual isotopic compositions of carbonate-cemented surface rocks: Geology, v. 2, p. 351-354. 
Donovan, T. J., Noble, R. C., Friedman, I., and Gleason, J. D., 1975, A possible petroleum-related geochemical anomaly in surface rocks, Boulder and Weld Counties, Colorado: U.S. Geol. Survey Open-File Rept. 75-47.

Elkins, T. A., 1951, The second derivative method of gravity interpretation: Geophysics, v. 16, p. 29-50.

Epstein, S., Graf, D. L., and Degens, E. T., 1964, Oxygen isotope studies on the origin of dolomites, in Craig, Harmon, and others, eds., Isotope and Cosmic Chemistry: Amsterdam, North-Holland Pub. Co., p. 169-180.

Estabrook, 1925, Analyses of Wyoming oil field craters: Am. Assoc. Petroleum Geologists Bul1., v. 9, p. 235-246.

Euchen, A., and Hertzberg, G., 1950, Aus Salzeffeht und Ionenhydration: Zeitschr. Phys. Chemic., v. 195, p. 1-23.

Evans, C. R., Rogers, M. A., and Bailey, N. J. L., 1971, Evolution and alteration of petroleum in western Canada: Chem. Geology, v. 8, p. 147-170.

Eyraud, C., Sapet, J. C., and Daneyro11e, C., 1963, Enrichissement isotopique du melange $\mathrm{H}_{2} \mathrm{O}-\mathrm{DHO}$ par econlement en phase adsorbee: Jour. Chemic. Physique et de physico-chemic Biologeque, v. 60, p. 285-288.

Feely, H. W., and Kulp, J. L., 1957, Origin of Gulf Coast salt-dome sulfur deposits: Am. Assoc. Petroleum Geologists Bull., v. 41, p. 1802-1853.

Freeze, R. A., 1966, Theoretical analysis of regional groundwater flow: Berkeley, Univ. of California, Ph. D. thesis, 318 p. 1969, Theoretical analysis of regional groundwater flow: Canada Inland Waters Branch, Sci. Ser. 3.

Freeze, R. A., and Witherspoon, P. A., 1966, Theoretical analysis of regional groundwater flow; 1.--Analytical and numerical solutions to the mathematical model: Water Resources Research, v. 2, p. 641-656.

1967, Theoretical analysis of regional groundwater flow; 2.--Effect of water table configuration and subsurface permeability variation: Water Resources Research, v. 3, p. 623-634."

1968, Theoretical analysis of regional groundwater flow; 3.--Quantitative interpretations: Water Resources Research, v. 4, p. 581-590.

Fontes, J. C., and Gonfiantini, R., 1967, Comportement isotopique au cours de 1 'evaporation de deux Bassins Sahariens: Earth and Planetary Sci. Letters, v. 3, p. 258-266.

Galloway, John, 1943, Kettleman Hills oil fields: State of California Dept. Nat. Res., Geologic Formations and Economic Development of 0il and Gas Fields of California, Bul1. 118, p. 491-493.

Gardner, Frank, 1949, Ira Rinehart's west Texas oil, a study of the petroleum industry in fifty-five counties of the west Texas Permian Basin: Dallas, Rinehart Oil News Co., p. 211.

George, H. C., and Bunn, J. R., 1924, Petroleum engineering in the Fox and Graham 011 and Gas Fields, Carter County, Oklahoma: Washington, U.S. Bureau Mines, 81 p.

Goetz, A. F. H., 1975, Use of ERTS and other correlative data, in Goetz, A. F., and others, Application of ERTS images and image processing to regional geologic problems and geologic mapping in northern Arizona: Jet Prop. Lab., Calif. Inst. Tech. (NASA) Tech. Rept. 32-1597, p. 4-12.

Gouin, F., 1956, Surface criteria of southern Oklahoma oil fields, in Petroleum geology of southern Oklahoma: Tulsa, Okla., Am. Assoc. Petroleum Geologists, v. 1 , p. 14-35.

Graf, D. L., Friedman, I., and Meents, W. F., 1965, The origin of saline formation waters, II--Isotopic fractionation by shale micropore system: Illinois Geol. Survey Circ. 393, 32 p. 
Graf, D. L., Meents, W. F., Friedman, I., and Shimp, N. F., 1966, The origin of saline formation waters, III--Calcium Chloride Waters: Illinois Geol. Survey Circ. 397, 60 p.

Haeberle, F. R., 1951, Relationship of hydrocarbon gravities to facies in Gulf Coast: Am. Assoc. Petroleum Geologists Bull., v. 35.

Halbouty, M. T., 1968, Giant oil and gas fields in the United States: Am. Assoc. Petroleum Geologists Bul1., v. 52, p. 1115-1151.

Hanshaw, B. B., 1962, Membrane properties of compacted clays: Harvard Univ., $\mathrm{Ph}$. D. thesis, $113 \mathrm{p}$.

Hanshaw, B. B., and Coplen, T. B., 1973, U1trafiltration by a compacted clay membrane; II.--Sodium ion exclusion at various ionic strengths: Geochim. et Cosmochim. Acta, v. 37, p. 2311-2327.

Hanshaw, B. B., and Hill, G. A., 1969, Geochemistry and hydrodynamics of the Paradox basin region, Utah, Colorado, and New Mexico: Chem. Geology, v. 4, p. 263-294.

Hanshaw, B. B., and Zen, E-an, 1965, Osmotic equilibrium and overthrust faulting: Geo1. Soc. America Bul1., v. 76, p. 1379-1386.

Harlton, B. H., 1960, Stratigraphy of Cement pool and adjacent area, Caddo and Grady Counties, Oklahoma: Am. Assoc. Petroleum Geologists Bull., v. 44, p. 210-226.

Hathaway, J. C., and Degens, E. T., 1968, Methane-derived marine carbonates of Pleistocene Age: Science, v. 165, p. 690-692.

Herrmann, T. A., 1961, Structural geology of Cement-Chuckasha area, Caddo and Grady Counties, Oklahoma: Am. Assoc. Petroleum Geologists Bu11., v. 45, p. 1971-1993.

Hitchon, Brian, 1969a, Fluid flow in the westerr Canada sedimentary basin. 1. Effect of topography: Water Resources Research, v. 5, p. 186-195. 1969b, Fluid flow in the western Canada sedimentary basin. 2. Effect of geology: Water Resources Research, v. 5, p. 460-469. 1974, Application of geochemistry to the search for crude oil and natural gas, in Levinson, A. A., Introduction to Exploration Geochemistry: Calgary, Applied Pub. Co., p. 509-554.

Hitchon, Brian, and Friedman, I., 1969, Geochemistry and origin of formation waters in the western Canada sedimentary basin--I Stable isotopes of hydrogen and oxygen: Geochim. et Cosmochim. Acta, v. 33, p. 1321-1349. Horvitz, L., 1939, On geochemical prospecting: Geophysics, v. 4, p. 210-228. Huber, M. E., Flood, E. A., and Heyding, R. D., 1956, Micropore flow of $\mathrm{H}_{2} \mathrm{O}$ and $\mathrm{D}_{2} \mathrm{O}$ through activated carbon rods: Canadian Jour. Chemistry, v. $34, \mathrm{p}$. 1288-1301.

Hunt, G. R., and Salisbury, J. W., 1970, Visible and near-infrared spectra of minerals and rocks; I--Silicate minerals: Modern Geology, v. 1, p. 283300.

Hunt, G. R., Salisbury, J. W., and Lenhoff, C. J., 1971, Visible and nearinfrared spectra of minerals and rocks; III--Oxides and hydroxides: Modern Geology, v. 2, p. 195-205.

Hunt, J. M., 1953, Composition of crude oil and its relation to stratigraphy in Wyoming: Am. Assoc. Petroleum Geologists Bul1., v. 37, p. 1837-1872.

I11ing, V. C., 1938, The significance of surface indications of oil, in The science of Petroleum: London, Oxford University Press, v. 1, p. 294-296.

Jones, T. S., and Smith, H. M., 1965, Relationships of oil accumulation and stratigraphy in the Permian basin of west Texas and New Mexico, in Young, A., and Galley, J. E., eds., Fluids in subsurface environments: Am. Assoc. Petroleum Geologists Mem. 4, p. 101-224. 
Kartsev, A. A., Tabasaranskii, Z. A., Subbota, M. I., and Mogilevskii, G. A., 1959, Geochemical methods of prospecting and exploration for petroleum and natural gas: Berkeley, Univ. of California Press, 349 p. (trans. from Russian).

Kharaka, Y. K., Berry, F. A. F., and Friedman, I., 1973, Isotopic composition of oil field brines from Kettleman North Dome, California and their geologic implications: Geochim. et Cosmochim. Acta, v. 37, p. 1899-1908.

Kharaka, Y. K., Callender, E., and Wallace, R. H., Jr., 1977, Geochemistry of geopressured geothermal waters from the Frio clay in the Gulf Coast region of Texas: Geology, v. 5, p. 241-244.

Kirkland, D. W., and Evans, R., 1976, Origin of limestone buttes, Gypsum plain, Culberson County, Texas: Am. Assoc. Petroleum Geologists Bull., v. 60, p. 2005-2018.

Krauskopf, K. B., 1957, Separation of manganese from iron in sedimentary processes: Geochim. et Cosmochim. Acta, v. 12, p. 61-68.

Krejci-Graf, K., 1963, Origin of oil: Geophys. Prosp., v. 11, p. 244-275.

Laubmeyer, G., 1933, Eine neue geophysikalische Schurfmethode insbesondere fur Kohlenwasserstoff-Lagerstatten: Petroleum, v. 29, no. 18, p. 1-4.

Levorsen, A. I., and Berry, F. A. F., 1967, Geology of petroleum, 2d ed.: San Francisco, W. H. Freeman, 724 p.

Link, W. K., 1952, Significance of oil and gas seeps in World oil exploration: Am. Assoc. Petroleum Geologists Bul1., v. 36, p. 1505-1540.

Longsworth, L. G., 1960, The mutual diffusion of light and heavy water: Jour. Phys. Chemistry, v. 64, p. 1914-1917.

Mallory, William W., 1948, Pennsylvanian stratigraphy and structure, Velma Pool, Stephens County, Oklahoma: Am. Assoc. Petroleum Geologists Bul1., v. 32 , no. 10 , p. 1948-1979.

Mamchur, G. P., 1969, Isotopic composition of carbon in calcite paragenetic with sulfur: Geochemistry Internat., v. 6, p. 660-670.

Maxim, L. D., and Cullen, D. E., 1977, A cost model for remote inspection of ground sites: Photogrammetric Engineering and Remote Sensing, v. 43, p. 1009-1026.

McAllister, E. W., 1941, Development and application of surface pressure data in Kettleman Hills: Petroleum Development and Technology, v. 142, p. 3955.

McAuliffe, C., 1963, Solubility in water of $C_{1}-C_{9}$ hydrocarbons: Nature, v. 200, p. 1092-1093.

McCrea, J. M., 1950, On the isotopic chemistry of carbonates and a paleotemperature scale: Jour. Chem. Physics, v. 18, p. 849-857.

McCulloh, Thane, 1969, Oil fields, gravity anomalies, and surface chemical manifestations--correlations, causes, and exploration significance [abs.]: Soc. Explor. Geophysicists, Program, Pacific Sect. 44th Ann. Mtg., Los Angeles, Calif., 1969, p. 17-18.

McDevitt, W. F., and Long, F. A., 1952, The activity coefficient of benzene in aqueous salt solutions: Am. Chem. Soc. Jour., v. 74, p. 1773-1777.

McKelvey, J. G., and Milne, I. H., 1962, The flow of salt through composted clay, in Swineford, A., ed., Clays and clay minerals, v. 9, - 9th Natl. Conf. Clays and Clay Minerals, Proceedings: New York, Pergamon Press (Earth Sci. Ser. Mon. 11), p. 248-259.

McNab, J. G., Smith, P. V., and Betts, R. L., 1952, The evolution of petroleum: Industrial Eng. Chem., v. 44, p. 2556-2563.

McNeal, Robert P., 1961, Hydrodynamic entrapment of oil and gas in Bisti Field, San Juan County, New Mexico: Am. Assoc. Petroleum Geologists Bull., v. 45, no. 3, p. 315-329. 
Mil1s, R. V. A., and Wells, R. C., 1919, The evaporation and concentration of waters associated with petroleum and natural gas: U.S. Geol. Survey Bull. 693, $104 \mathrm{p}$.

Murata, K. J., Friedman, I., and Madsen, B. M., 1969, Isotopic composition of diagenetic carbonates in marine miocene formations of California and Oregon: U.S. Geo1. Survey Prof. Paper 614-B, 24 p.

Nisle, R. G., 1941, Considerations on the vertical migration of gases: Geophysics, v. 6, p. 449-454.

Owen, E. W., 1975, Trek of the oil finders: A history of exploration for petroleum: Am. Assoc. Petroleum Geologists Mem. 6, 1647 p.

Pandey, G. N., Rosin Tek, M., and Katz, D. L., 1974, Diffusion of fluids through porous media with implications in petroleum geology: Am. Assoc. Petroleum Geologists Bul1., v. 58, no. 2, p. 291-303.

Paul, M. A., 1952, The solubilities of naphthalene and biphenyl in aqueous solutions of electrolytes: Am. Chem. Soc. Jour., v. 74, p. 5274-5277.

Perkin-Elmer, 1973, Analytical methods for atomic absorption spectrophotometry: Norwalk, Conn., Perkin-Elmer Corp., loose-1eaf, with supplements.

Pirson, S. J., 1940, Critical survey of recent developments in geochemical prospecting: Am. Assoc. Petroleum Geologists Bu11., v. 24, p. 1464-1474.

Price, L. C., 1976, Aqueous solubility of petroleum as applied to its origin and primary migration: Am. Assoc. Petroleum Geologists Bull., v. 60, p. 213-244.

Radler, Dollie, 1930, 0il and gas in Oklahoma, Lincoln County: Oklahoma Geol. Survey Bu1l. 40, v. III, p. 599-611.

Reed, C., 1910, Geological and mineral resources of the Arbuckle Mountains, Oklahoma: U.S. Geol. Survey Bull. 726, f. 41-85.

Reeves, F., 1922, Geology of the Cement oil field, Caddo County, Oklahoma: U.S. Geol. Survey Bu11. 726, pt. 2, p. 41-85.

Roberts, A. A., Dalziel, M. C., Pogorski, L. A., and Quirt, S. G., 1976, A possible petroleum related helium anomaly in the soil gas, Boulder and Weld Counties, Colorado: U.S. Geol. Survey Open-File Rept. 76-544.

Ralston, Wallace, and Rettger, R. E., 1956, Case history of the Jameson Reef Field, Coke County, Texas, in Lyons, P. L., ed., Geophysical Case Histories: Menasha, Wisc., Soc. of Exploration Geophysics, v. 2, p. 200-215.

Rosaire, E. E., 1940, Geochemical prospecting for petroleum: Am. Assoc. Petroleum Geologists Bul1., v. 24, p. 1400-1433.

Rutledge, R. B., 1956, The Velma oil field, Stephens County, Oklahoma, in Petroleum geology of southern Oklahoma--a symposium: Ardmore Geo1. Soc., v. 1 , p. 260-281.

Sabins, F. F., 1963, Anatomy of stratigraphic traps, Bisti Field, New Mexico: Am. Assoc. Petroleum Geologists Bull., v. 47, no. 2, p. 193-228.

Schmidt, G. W., 1973, Interstitial water composition and geochemistry of deep gulf coast shales and sandstones: Am. Assoc. Petroleum Geologists Bull., v. 57, p. $321-337$.

Sharma, T., and Clayton, R. N., 1965, Measurement of $0^{18 / 0^{16}}$ ratios of total oxygen from carbonates: Geochim. et Cosmochim. Acta, v. 29, p. 1347-1353.

Sokolov, V. A., 1933, New method of surveying oil and gas formations: Tekhn. Nefti., v. 16, p. 163.

Stanton, R. J., and Dodd, J. R., 1970, Paleoecologic techniques-comparison of faunal and geochemical analyses of Pliocene paleoenvironments, Kettleman Hills, California: Jour. Paleontology, v. 44, p. 1092-1121.

storm, Willis, 1921, The Velma oil and gas field, Stephens County, Oklahoma: Am. Assoc. Petroleum Geologists Bull., v. 5, no. 5, p. 628. 
Thode, H. G., Wanless, R. K., and Wallouch, R., 1953, The origin of Texas and Louisiana sulphur deposits from isotope fractionation studies: Natl.

Research Council Comm. Nuclear Sci., Conf. on Nuclear Processes in Geologic Settings, 1953, Proc., p. 57-63.

Thompson, A. B., 1926, The significance of surface ofl indications: Jour. Inst. Petrol. Technology, v. 12, p. 603-622.

Tomilson, C. W., 1952, Odd geological structures of southern Oklahoma: Am. Assoc. Petroleum Geologists Bu11., v. 36, no. 9, p. 1820-1840.

Tomilson, C. W., and Storm, Willis, 1924, The Graham field, Oklahoma: Am. Assoc. Petroleum Geologists Bull., v. 8, no. 5, p. 593-620.

Tomkins, J. Q., 1957, The Bisti oil field, New Mexico: Am. Assoc. Petroleum Geologists Bul1., v. 41, no. 5, p. 906-922.

Toth, J., 1962, A theory of groundwater motion in small drainage basins in central Alberta, Canada: Jour. Geophys. Research, v. 67, p. 4375-4387. 1963, A theoretical analysis of groundwater flow in small drainage basins: Jour. Geophys. Research, v. 68, p. 4795-4812. 1972, Groundwater motion in drainage basins, in Fairbridge, R. W., Encyclopedia of geochemistry and environmental sciences: New York, Van Nostrand Reinhold, p. 478-487.

Uspenskii, V. A., Gorshaya, A. I., and Karpova, I. P., 1947, The formation of algarite and the process of anaerobic oxidation of petroleum: Izv. Akad. Nauk. SSSR, Ser. Geol., v. 4, p. 89-106.

Veizer, J., and Hoefs, J., 1976, The nature of $0^{18 / 0^{16}}$ and $\mathrm{C}^{13} / \mathrm{C}^{12}$ secular trends in sedimentary carbonate rocks: Geochim. et Cosmochim. Acta, v. 40, p. 1387-1395.

Weeks, L. G., 1958, Habitat of oil and some factors that control it, in Weeks, L. G., ed., Habitat of oil: Tulsa, Okla., Am. Assoc. Petroleum Geologists, p. 1-61.

White, S. B., 1941, Davenport Field, Lincoln County, Oklahoma, in Levorsen, A. I., ed., Stratigraphic type oil fields: Tulsa, Okla., Am. Assoc. Petroleum Geologists Bu11., p. 386-407.

Winters, J. C., and Williams, J. A., 1969, Microbiological alteration of crude oil in the reservoir, in Petroleum transformations in geologic environments-a symposium: Am. Chem. Soc., New York City Meeting, Sept. 7-12, p. E22E31.

Woodring, W. I., Stewart, R., and Richards, R., 1940, Geology of the Kettleman Hills oil field, California--Stratigraphy, paleontology and structure: U.S. Geol. Survey Prof. Paper 195, 170 p.

Yungul, S. H., Hembree, M. R., and Greenhouse, J. P., 1973, Telluric anomalies associated with isolated reefs in the Midland Basin, Texas: Geophysics, v. 38 , p. $545-556$.

Zaitsev, I. K., and Baskov, E. A., 1969, Basic features of hydrochemical zoning of platform regions and its value in the study of secondary alteration of sedimentary rocks: Lithology and Mineral Resources, v. 4, p. 722-732. 